\title{
Tracing the Human Past: The Art of Writing Between Human Ingenuity and Divine Agency in Early Modern World History
}

\author{
Jetze Touber
}

\begin{abstract}
In this chapter, Jetze Touber examines the changing views on the history of writing, in the context of 'early modern world history'. Early modern efforts to reconstruct the origin of the art of writing in various parts of the globe problematised the relation of 'world history' to biblical history as a divinely laid out, providential path of human development. Touber shows how in the seventeenth century scholars generally agreed that the ancient Hebrews, God's Chosen People, had acquired the alphabetic script as a divine gift. A century later, however, the Encyclopédie ascribed the origin of the alphabet to an anonymous Egyptian scribe, who developed it as a secret code for government administration, impenetrable for the uninitiated. The correspondence of Gijsbert Cuper, magistrate and antiquarian, with an extensive network of international contacts, provides a unique window through which we can observe how the evolving reconstruction of the history of alphabetic writing impacted on world history. Around 1700 Cuper and his correspondents discussed the then recently discovered inscriptions in a variety of antique scripts from around the world. Getting access to and making sense of inscribed artefacts required collective effort. It also required special skills in faithfully reproducing letters. The study of inscriptions acquired some of the characteristics of the natural sciences, with their increasing sophistication in graphic reproduction. Scholars studying ancient scripts in this period might ignore the deciphering of texts, and focus on letterforms, in order to trace the diffusion of peoples from Paradise and the ancient Israelites. The discovery of an apparently very ancient Sinhalese culture using characters that did not compare to any known script, associated, moreover, with images that seemed to support the pre-Adamite thesis of La Peyrère, proved especially disturbing. Eventually, with more accurate insight in the forms of letters, the suspicion grew that the traditional genealogy of mankind, based on biblical narrative, was false.
\end{abstract}

(C) JETZE TOUBER, 2019 | DOI:10.1163/9789004389397_004

This is an open access chapter distributed under the terms of the prevailing CC-BY-NC License at the time of publication. 
In August 1713, Gijsbert Cuper (1644-1716), burgomaster of Deventer and an internationally renowned scholar, articulated a number of questions that interested him about the island of Ceylon, prompted to do so by his friend Nicolaas Witsen (1641-1717). He asked

whether several nations live on that island; when they have come; whether they are all of one belief, or some Muslims and the others idolaters; what kind of Idols they worship; whether there is one language throughout the island; what kind of chronology they have; and whether any memory lives on of sea voyages undertaken by other nations to that island. ${ }^{1}$

This short list of questions, which combines ethnography and antiquarianism, is typical of the range of topics that informed early modern accounts of newly encountered peoples. Since the sixteenth century Europeans had collected observations of other cultures with the aim of embedding them in the received narrative of humankind's history and its relation to the Creator. The Bible seemed to give a straightforward account of the origin of the world, of humankind, and of human culture. However, there was much room left for the details to be filled in. In piecing together the details of world history, early modern Christian scholars increasingly found it difficult to maintain a coherent narrative within the biblical framework. In this chapter, I will examine a particular kind of cultural artifact that complicated the received wisdom concerning the historical development of humankind: the many alphabets newly encountered across the globe.

Several historians have looked at the broad intellectual debate that transformed the way Europeans conceived of the Bible as a source of cosmogonic knowledge. The histories of the earth, of nature, and of human societies and culture were heavily interdependent on one another in discussions among early modern scholars, who regarded the Bible as the most authoritative source for all these topics. We may call this complex of discussions 'early modern world history.' Paolo Rossi traced the development of geological and of linguistic

1 "Off gheen diversse volkeren woonen op dat Eylant, wanneer die daer zyn gekoomen; of altemael van een geloof zyn, dan of de eenen zyn Mahometaens, ende de andere afgoodendienaers, wat voor soorten van Afgoeden zy aenbidden; of de taal het geheele eyland door eene ende deselfsde is; hoe dat haare tydt rekeninghen zyn; en of gheen heugenisse aldaer is overgebleeven van scheepvaarden by andere volkeren daer op ondernoomen." Letter of G. Cuper to N. Witsen (14 August 1713), Amsterdam, Library University of Amsterdam [hereafter: UBA], MS Be 74 . 
thought between $165^{\circ}$ and 1750, when theories about the antiquity of both the world itself and human culture changed rapidly, irreversibly dissociating nature and culture. ${ }^{2}$ Along similar lines, authors have more recently suggested how hermeneutics and natural history were interconnected within more circumscribed historical contexts. ${ }^{3}$ Within this 'early modern world history,' the great variety of letterforms used in writing, around the world and throughout history, merits particular attention, being positioned at the interface between human culture and the material world.

Historians, insofar as they have examined early modern perceptions of the history of writing as a technique, have focused on ideas about human communication and epistemology, leaning heavily on published treatises and journal articles. ${ }^{4}$ These ideas, however, grew out of early modern travelers' and scholars' experience with scripts actually encountered on paper, in stone, and on metal. Little serious attention has been given to an essential precondition: the actual observation and reproduction of the letterforms of scripts. The challenges posed by the material reproduction of scripts in the service of reconstructing the global history of languages have hardly been explored. To delve into this area requires that we pay greater attention to the way graphic materials were approached, copied, exchanged, and examined in correspondence and in manuscript volumes. This chapter will argue that intensified commerce with the Middle East, Asia, and the Americas necessitated more hands-on dealings with a greater variation of letterforms than had previously been imagined. This in turn increased awareness of the variety of human experience, and made a coherent, divinely-laid-out, providential path of human development seem less plausible. I will closely scrutinize how the alphabet and thus the art of writing - that most fundamental of human technologies - lost their anchoring in biblical history.

This chapter will thus explore how the discovery, reproduction, and examination of letterforms from around the world informed changing perceptions of 'early modern world history'. It is important to note that I will focus on the early modern conceptualization of the history of the alphabet, a limited set of graphic signs denoting the sounds that constitute spoken words. I refer to alphabets as phonographic script, as opposed to ideographic script—graphic

2 Paolo Rossi, I segni del tempo: storia della terra e storia delle nazioni da Hooke a Vico (Milan, 1979).

3 E.g., William Poole, The World Makers: Scientists of the Restoration and the Search for the Origins of the Earth (Oxford, 2010); Eric Jorink, Reading the Book of Nature in the Dutch Golden Age, 1575-1715 (Leiden, 2010).

4 Besides Rossi and Poole, important publications in this respect are Paul Cornelius, Languages in Seventeenth- and Early Eighteenth-Century Imaginary Voyages (Geneva, 1965); Nicholas Hudson, Writing and European Thought, 160o-1830 (Cambridge, 1994). 
symbols such as hieroglyphs that represent concepts. Recent work on the entanglement of antiquarianism and orientalism has explored the fascination for ideographic writing, including seventeenth-century attempts to associate the newly encountered Chinese characters with ancient Egyptian hieroglyphs. ${ }^{5}$ Speculation about hieroglyphs, however, was only part of the story, as important as it was in early modern intellectual history. Early modern scholars came to realize the vastness and variety of human experience through phonographic writing as well. Grasping the many different marks used for writing across the world made it ever less plausible that they could all be traced back to one single, divinely endowed writing system.

Gijsbert Cuper (1644-1716) is an excellent gauge for these developments, because his biography coincides exactly with the decades investigated in this book. We will accompany Cuper as he received, pondered, and discussed ancient inscriptions, newly discovered across Eurasia. Starting out as a classical scholar, Cuper was exposed in the second half of his life to increasingly diverse scripts from various parts of the world. In the examination of the shapes of these letters, the variability of writing through time and space thrust itself on Cuper and his friends. The existing neat genealogy, tracing human cultures back to the first people mentioned in the Bible, became unsustainable in light of the variety of material realizations of writing now encountered by the Europeans.

To get an idea of the changes in how the art of writing was incorporated into early modern world history during the decades when Cuper was working, it is useful to consider two landmark publications, one published during Cuper's youth, the other more than a half century after his death. Published in 1657, the London Polyglot was a massive edition of biblical texts in Latin, Greek, Hebrew, Syrian, Arabic, Aramaic, and Ethiopian. An introductory essay by the work's main editor, Brian Walton (160o-61), treated the history of writing. This essay from the middle of the seventeenth century reflects the assumption that, in one way or another, the biblical texts were central to the history of writing as a human achievement. More than a century later, in 1782 , this assumption had receded to the background, if it had not vanished altogether. For this evolution in thinking we can turn to the renowned Encyclopédie ou Dictionnaire

5 Thijs Weststeijn, 'From Hieroglyphs to Universal Characters: Pictography in the Early Modern Netherlands,' Nederlandsch Kunsthistorisch Jaarboek 61 (2011), 238-81, there 249-54; Daniel Stolzenberg, Egyptian Oedipus: Athanasius Kircher and the Secrets of Antiquity (Chicago, 2013), pp. 226-43. See also the contribution of Trudelien van 't Hof to this volume. 
Raisonnée, edited under the supervision of Jean le Rond d'Alembert (1717-83) and Denis Diderot (1713-84) and intended to bring together all current professional knowledge. An Encyclopédie article on the history of writing discussed subject matter that was similar to what Walton took up in his essay. This entry, however, more or less reversed the traditional account of writing's history. The alphabet, long considered a divine gift, was now regarded as a set of arbitrary signs, ingenious but also arcane, a system to be mastered by human minds rather than something that God had bestowed.

The London Polyglot was fourth and last in a series of multilingual Bibles, starting with the so-called Complutensian, published by Spanish humanists in Alcalá de Henares in 1520. The polyglot genre had been born out of the humanist aspiration to make available to scholars all versions of the biblical text in the original languages. The production of these Bibles was tremendously costly in part because of the difficulty of printing a single publication that required a variety of scripts: Latin, Greek, and several Semitic ones. The London Polyglot, once it was realized in 1657 despite financial, technical and political obstacles, became a major reference work for European scholarship, not least because of its authoritative introductory materials - which included, as noted, an essay on the history of writing. ${ }^{6}$

In this essay, the volume's chief editor Walton extolls writing as a great wonder. His admiration is directed exclusively at phonographic writing. He claims that even the Chinese, who were proud of their own ideographic characters, had been deeply struck by the fact that Europeans were able to fix the sounds of the Chinese language on paper, allowing even those who did not know a single word of the language to reproduce its sounds. Walton gives the honor of inventing phonographic characters to the Hebrews. He surmises that before the Flood, human beings had already known how to write. Adam, probably, had invented a version of the Hebrew script. After the Flood the Hebrews preserved their letters, which allowed the people surrounding them, the Assyrians, to derive their own alphabet. The original Hebrew letters were not, however, those of the Hebrew script as Walton and his seventeenth-century contemporaries knew it. Rather, the original letters were the so-called Samaritan letters. Only much later, when the Jews returned from Babylon to Jerusalem in the fifth century BCE, did they bring along the set of characters that the Assyrians had derived from these original Samaritan letters. The new alphabet was called

6 Peter N. Miller, "The "Antiquarianization" of Biblical Scholarship and the London Polyglot Bible (1653-57), Journal of the History of Ideas 62 (2001), 463-82. 
the Quadrata (or, confusingly enough, the Assyrian script), supposedly the variant of the Hebrew script in use among the Jews ever since. ${ }^{7}$

This genealogy was how the advanced philologists of the time conceived the history of the alphabet: an original that developed into the Samaritan, from which the Assyrians derived the variant of the Quadrata, which the Jews subsequently adopted and still used in the early modern period. Scholars all over Europe-Azariah de' Rossi (ca. 1511-78), Juan Bautista Villalpando (1552-16o8), Joseph Justus Scaliger (1540-1609), Gerardus Johannes Vossius (1583-1645), to name a few-submitted to this account of how writing had entered the world and had spread. ${ }^{8}$ Already in 1538 the Parisian orientalist Guillaume Postel (1510-81) had sketched more or less the same history of the Hebrew script: returning from the Babylonian Captivity, Ezra discarded the ancient Hebrew alphabet that by then had come into use among the despised Samaritans (and which was called, accordingly, the Samaritan). As an alternative Ezra had introduced the Quadrata, the Assyrian variant that the Hebrews had already begun to use in Babylon. ${ }^{9}$

For all its scholarly sophistication, Walton's reconstruction of the history of writing fit perfectly with a providential view of world history. Sure enough, Walton accommodated the variants of the Hebrew script in a model of historical change - the Samaritan script was the original, the 'Assyrian' Quadrata was a derivative. He was cautious and noncommittal about the antediluvian history of writing, merely suggesting rather than claiming definitively that Adam, his son Seth, and their descendants had introduced the Samaritan alphabet. Nonetheless, the Hebrew phonographic alphabet was central to Walton's history of writing. Significantly, he accorded an inferior status to the Egyptian, Chinese, and Mexican scripts on account of the ideographic nature of each. To the superior, phonographic Hebrew letters he attributed a monogenetic origin closely bound up with the history of the Chosen People. ${ }^{10}$

This last of the polyglots appeared at a crucial juncture in the history of biblical scholarship. Both Thomas Hobbes (1588-1679) and Isaac La Peyrère (ca. 1596-1676) had recently published the works with which they were to make

Brian Walton, 'Prolegomenon II. De literis sive characteribus,' in: Biblia sacra polyglotta, ed. Brian Walton (London, 1657), pp. 6-8.

8 Cornelius, Languages (see above, n. 4), pp. 5-23; cf. the anonymous (Richard Simon?), 'Dissertation critique sur les anciennes lettres des Hebreux,' Bibliothèque critique 2 (1708), 389-417, there 391; see Hudson, Writing and European Thought (see above, n. 4), p. 35, who states that "Walton, more daringly, claimed that Adam's letters were Samaritan rather than Hebrew." It is unclear why such a claim would have been daring.

9 Guillaume Postel, Linguarum duodecim characteribus differentium alphabetum, introductio (Paris, 1538), fols. (Cii) v-(Ciiii)v.

10 Walton, 'Prolegomenon II' (see above, n. 7). 
their marks in the field - even if, or maybe precisely because, this field was not their primary concern at all. Hobbes's Leviathan (1651) presented human history as the product of impersonal social forces acting within a morally neutral mass of self-centered human individuals. Expounding his political theory, Hobbes cursorily identified the Bible as originating in fifth-century Palestine as an expedient instrument of political dominance. ${ }^{11}$ La Peyrère's Prae-adamitae (1655) was a millenarian project in which the author argued for a union between Christians and Jews. La Peyrère narrowed the scope of the Bible by capitalizing on the presence of two Creation stories, the first (Genesis 1) purportedly narrating the creation of humankind in general, and the second (Genesis 2) being limited to the creation of Adam, the ancestor of the Jews. This allowed him to reduce the rest of the Bible to a history of the Jewish people only-creating a potentially enormous span of time between the general Creation and the specific Creation, an interval about which Europeans knew virtually nothing. ${ }^{2}$ These interventions by relative outsiders compromised the notion that the Bible was the ultimate source of world history. Walton's introductory essays to the London Polyglot represented the culmination of generations of biblical philology, achieved, however, at a moment when biblical scholarship was about to irrevocably lose its exclusive claim to world history.

After Walton, there were significant changes in the way that the introduction of writing into the world was reconstructed. The hieroglyphic script of Egypt ceased to be imagined as a system of writing parallel to the Hebrew alphabet, hiding esoteric wisdom, as Renaissance scholars from Pierio Valeriano (1477-1558) down to Athanasius Kircher (1602-80) had believed. Starting with the Christian apologist Edward Stillingfleet (1635-99) and continuing down to the controversial British divine William Warburton (1698-1779), northern European scholars downplayed the significance of hieroglyphs, judging them not to be subtle and mysterious symbols but rather the manifestations of a crude attempt at written communication: infantile doodles, not arcane tokens. The alphabet came to be conceived of as a simpler and therefore more ingenious and elegant system of signs, capable of conveying complex thought. Warburton thought, as had John Woodward (ca. 1665-1728), that due to its higher degree of abstraction, this phonographic alphabet was more sophisticated than ideographic hieroglyphs. Its complexity necessitated a more advanced human culture, prompting Woodward and Warburton to posit a

\footnotetext{
11 Noel Malcolm, Aspects of Hobbes (Oxford, 2002), pp. 383-431.

12 Richard Popkin, Isaac La Peyrère (1596-1676). His Life, Work and Influence (Leiden, 1987); Andreas N. Pietsch, Isaac La Peyrère: Bibelkritik, Philosemitismus und Patronage in der Gelehrtenrepublik des 17.Jahrhunderts (Berlin, 2012).
} 
much later, postdiluvian dating of the alphabet's origin as compared with the infantile hieroglyphs. ${ }^{13}$

This speculation was a first step in detaching the history of writing from the biblically informed history of humankind. What it might lead to becomes clear from the aforementioned article devoted to the art of writing in the Encyclopédie (volume eleven, 1782). Unlike Walton, its author, Louis de Jaucourt (1704-79), does not speculate about the Adamic origins of writing. The encyclopédiste does not mention the Flood or the post-Babel confusion of languages, and in fact makes no reference to the Bible. He does not even attempt to identify the first script. He simply ascribes to an Egyptian official the brilliant idea of breaking down speech into a distinct number of sounds. From there, writes Jaucourt, it was only a small step to inventing a graphical system to represent those sounds, rather than ideas.

The technique of writing, Jaucourt claims, started out with people drawing graphic representations of the objects of their thoughts: "écriture en peinture." Subsequently peoples thought of devices to simplify the art. The Egyptian hieroglyphs were examples of such simplifications. Nevertheless, they remained ideographic characters. The use of an alphabet, which transposes the sounds of words to marks on paper or some other surface, was something entirely different. In a stroke of genius, an official under the Egyptian pharaoh Thoth had realized that speech actually consists of only a limited number of sounds. Once a system was devised to render these sounds graphically, this first alphabet came into being. But it was first used exclusively for correspondence about state affairs. Commoners had no knowledge of this phonographic script.

Jaucourt signals an important change compared with predecessors such as Walton. He implies that it actually requires effort to understand and interpret phonographic letterforms. According to him, originally the hieroglyphs appealed directly to the visual sense, rendering them legible even to unlettered peasants. Only over time were these forms stylized, losing their original relationship with the things they denoted and making it impossible for people to grasp their meanings quasi-intuitively. The alphabet, on the other hand, had originally been used to keep state affairs secret from the common people. It was accessible only to the select few who happened to know the system. It may have been a brilliant invention, but it was not instantly usable by everybody. It had its origins as an instrument of domination. Chosen arbitrarily, the alphabet's set of letterforms could have comprised any other group of marks. ${ }^{14}$

13 Rossi, I segni del tempo (see above, n. 2), pp. 232-381.

14 Louis de Jaucourt, 'Écriture,' in: Encyclopédie ou Dictionnaire Raisonnée, ed. Denis Diderot and Jean D'Alembert, 24 vols. (Lausanne, 1780-82), 11: 812-5. 
Jaucourt leaned heavily on Warburton's The Divine Legation of Moses (1738-41) for this new speculative history of the alphabet. ${ }^{15}$ It was a striking reversal of the cultural significance attributed to the alphabet's invention: instead of an intuitive system of written communication of a divine lucidity, it was now in Warburton and Jaucourt's accounts an arcane instrument, initially exclusive to government and only gradually gaining wider application. This new description also entailed the recognition that it was difficult mentally to couple arbitrarily chosen graphic signs with the sounds that constitute speech.

Walton's and Jaucourt's publications mark a significant shift between $165^{\circ}$ and $175^{\circ}$ in the way that writing was understood as a part of world historyconcurrently with the diminished authority accorded to Scripture as a source of world history by some critics, in the wake of the likes of Hobbes and La Peyrère. It is vital to observe that not only ideographic scripts (Egyptian hieroglyphs, Chinese characters) were now being evaluated by scholars in a profoundly different way but, in a parallel development, so were the phonographic scripts (Hebrew and other alphabets). Hieroglyphs and characters lost their attraction as polysemic storehouses of wisdom, leaving only a sense that communicating in pictures was infantile; the Hebrew legacy, for its part, lost its privileged status as the source of the most perfect system of graphic communication. The invention and use of the alphabet became detached from the Jewish protagonists of the Pentateuch. The former development signaled the transformation of an emblematic worldview, and the latter made all textual knowledge, even divine revelation, dependent on human ingenuity - a universal trait rather than a providentially ordained endowment.

\section{$3 \quad$ Antiquity in Script}

Gijsbert Cuper, a scholar and magistrate from the provincial town of Deventer, lived and worked as this shift was taking place. Cuper is known best for his correspondence with his peers, a diverse, numerous, and international group. ${ }^{16}$

15 William Warburton, The Divine Legation of Moses Demonstrated, 2 vols. (London, 1738-41).

16 On Cuper and his place in the Republic of Letters, see: Marion Peters, 'Nicolaes Witsen and Gijsbert Cuper: Two Seventeenth-Century Dutch Burgomasters and Their Gordian Knot,' LIAS 16 (1989), 111-50; Peter J. A. N. Rietbergen, 'C. C. Rumpf, G. Cuper and Cultural Relations between Sweden and the Dutch Republic during the Last Quarter of the 17th Century, in: Baltic Affairs, ed. J.Ph.S. Lemmink and J. S. A. M. van Koningsbrugge (Nijmegen, 1990), pp. 315-42; Anne Goldgar, Impolite Learning: Conduct and Community in the Republic of Letters (New Haven, 1995), pp. 56-9; Bianca Chen, 'Digging for Antiquities with Diplomats: Gisbert Cuper (1644-1716) and his Social Capital,' Republics of Letters: A Journal for the Study of Knowledge, Politics, and the Arts 1, no. 1 (May 1, 2009): http://arcade .stanford.edu/rofl/digging-antiquities-diplomats-gisbert-cuper-1644-1716-and-his-social- 
His letters testify to a lively interest in everything that fascinated scholars of the late seventeenth and early eighteenth centuries: antiquities, natural history, philosophy, and languages. Cuper himself excelled in a relatively limited range of subjects, though. Epigraphy and numismatics were his main areas of expertise. Over the course of his life, these specialties would direct him to the exciting subject of the origin of writing. The questions that, as we have seen, were continuously being asked by Walton and Jaucourt and also by Scaliger, Stillingfleet, and Warburton-When was the art of writing introduced? Was it a divine gift or the invention of human genius? Which letters constituted the first script? - were posed and explored repeatedly in Cuper's correspondence. As the years went by, it turns out, his vision broadened - and his confidence about being able to give unequivocal answers diminished.

As a young man, Cuper was mainly concerned with classical antiquity. ${ }^{17}$ He studied with Johann Friedrich Gronovius in Leiden, who trained him to be an excellent philologist. His first publication (1670) was a series of observationes, short philological essays on subjects of Greek and Roman history and literature. ${ }^{18}$ He then published two antiquarian studies, the first of a Roman statuette of Harpocrates, son of the Egyptian gods Osiris and Isis (Harpocrates, 1676), the second of a Greek marble relief depicting the deification of Homer (Apotheosis Homeri, 1683). ${ }^{19}$ The former was in the possession of Johannes Smetius (1636-1704), a collector of antiquities in Nijmegen. The latter had appeared in the Lazio countryside near Rome. Tellingly, even though in the treatise on the Egyptian god Harpocrates Cuper refers to its 'hieroglyphic' quality ("forma satis docet, illam antiquam, notam hieroglyphicam, atque adeo Aegyptorum numen esse"), he does not follow this up with a discussion of hieroglyphs. ${ }^{20} \mathrm{He}$ does not venture into the speculative Egyptology of contemporaries such as Kircher, and also Isaac Vossius (1618-89) and Georgius Hornius $(1620-70)$, in their debate on chronology. ${ }^{21} \mathrm{He}$ remains safely within the limits of Greek and Roman source materials, partly literary, partly epigraphical,

capital; Bianca Chen, 'Politics and Letters: Gisbert Cuper as a Servant of Two Republics,' in: Double Agents: Cultural and Political Brokerage in Early Modern Europe, ed. Marika Keblusek and Badeloch Vera Noldus (Leiden, 2011), pp. 71-93.

17 It is not quite right that Cuper "made his fame studying Egyptian religion" or that "his main interest was Egyptology", as claimed in Willemijn van Noord and Thijs Weststeijn, 'The Global Trajectory of Nicolaas Witsen's Chinese Mirror', The Rijksmuseum Bulletin 63 (2015), 325-61, there 340, 349. In fact, Cuper made his fame studying Greek and Roman classical culture, and his main interest was antiquity, quite generally.

18 Gijsbert Cuper, Observationum libri tres (Utrecht, 1670).

19 Gijsbert Cuper, Harpocrates (Amsterdam, 1676); idem, Apotheosis vel Consecratio Homeri (Amsterdam, 1683).

20 Cuper, Harpocrates (see above, n. 19), p. 5 .

21 Weststeijn, 'From Hieroglyphs to Universal Characters' (see above, n. 5), 249-54. 
partly numismatic. Until he was 45 years old, there is little sign that Cuper was interested in anything other than classical and biblical culture-materialized in manuscripts and books, inscriptions, sculpture, and medals. This was to change, however, due to the arrival of ancient fragments from further afield. I will review these in the order Cuper obtained them.

In 1691 English travelers discovered the ruins of Palmyra in present-day Syria. ${ }^{22}$ The discovery made a great impact. Palmyra occurs in the Bible as a fortification of King Solomon. ${ }^{23}$ The ruins, therefore, potentially held traces of the Judaic kingdom, even from before the split of the Hebrew polity into two rival states under Jeroboam and Rehoboam. Cuper was among the first to receive the travel report, which included a sample Palmyrene inscription using letters that, although unknown, were thought to be related to Hebrew (Fig. 2.1). ${ }^{24}$

The travel report, together with the inscription, was published in 1695 by the English orientalist Thomas Smith (1638-1710) in the Philosophical Transactions (Fig. 2.2). Meanwhile, Cuper enlisted his friends to discuss the purport of the inscription. ${ }^{25}$ Cuper himself, one should note, could not read Hebrew or any other Eastern language. He was completely dependent on acquaintances to make sense of the letters of the Palmyrene inscription. One such acquaintance was Jacobus Rhenferd (1654-1712), a professor of Eastern languages in Franeker. Rhenferd aspired to construct an all-encompassing grammar of Near Eastern languages, as appears from a disputation held under his supervision: Rudimenta grammaticae harmonicae linguarum orientalium (1706). Evidently, Rhenferd was thrilled by the discovery at Palmyra. In 1704, he published a book about the Palmyrene alphabet. ${ }^{26}$ Below we will see that for several years Cuper functioned as a conduit between Rhenferd and several other European scholars actively studying languages and scripts (such as Mathurin Veyssière de La Croze [1661-1739] and Francesco Bianchini [1662-1729]).

The Palmyrene alphabet was still within the purview of biblical tradition. This was not the case with antiquities arriving after 1700. In 1703 Cuper's friend Nicolaas Witsen, a burgomaster of Amsterdam and administrator of the Dutch

22 For the circumstances of the discovery of Palmyra: Chen, 'Digging for Antiquities' (see above, n. 16); Chen, 'Politics and Letters' (see above, n. 16).

232 Chronicles $8,4$.

24 Cuper compiled a file of documents relating to the discovery of Palmyra, including a copy of the English travel report, a copy of the Dutch translation which Cornelis de Bruyn had inserted in his itinerary, and several letters discussing the significance of the discovery: The Hague, Koninklijke Bibliotheek [hereafter: KB], MS ${ }_{72} \mathrm{C}_{3}$.

25 For the publication history of the travel report see Chen, 'Politics and Letters' (see above, n. 16), pp. 89-92.

26 I consulted Periculum Palmyrenum in the posthumous edition of Rhenferd's works: Jacob Rhenferd, Opera philologica, ed. D. Mill (Utrecht, 1722). 


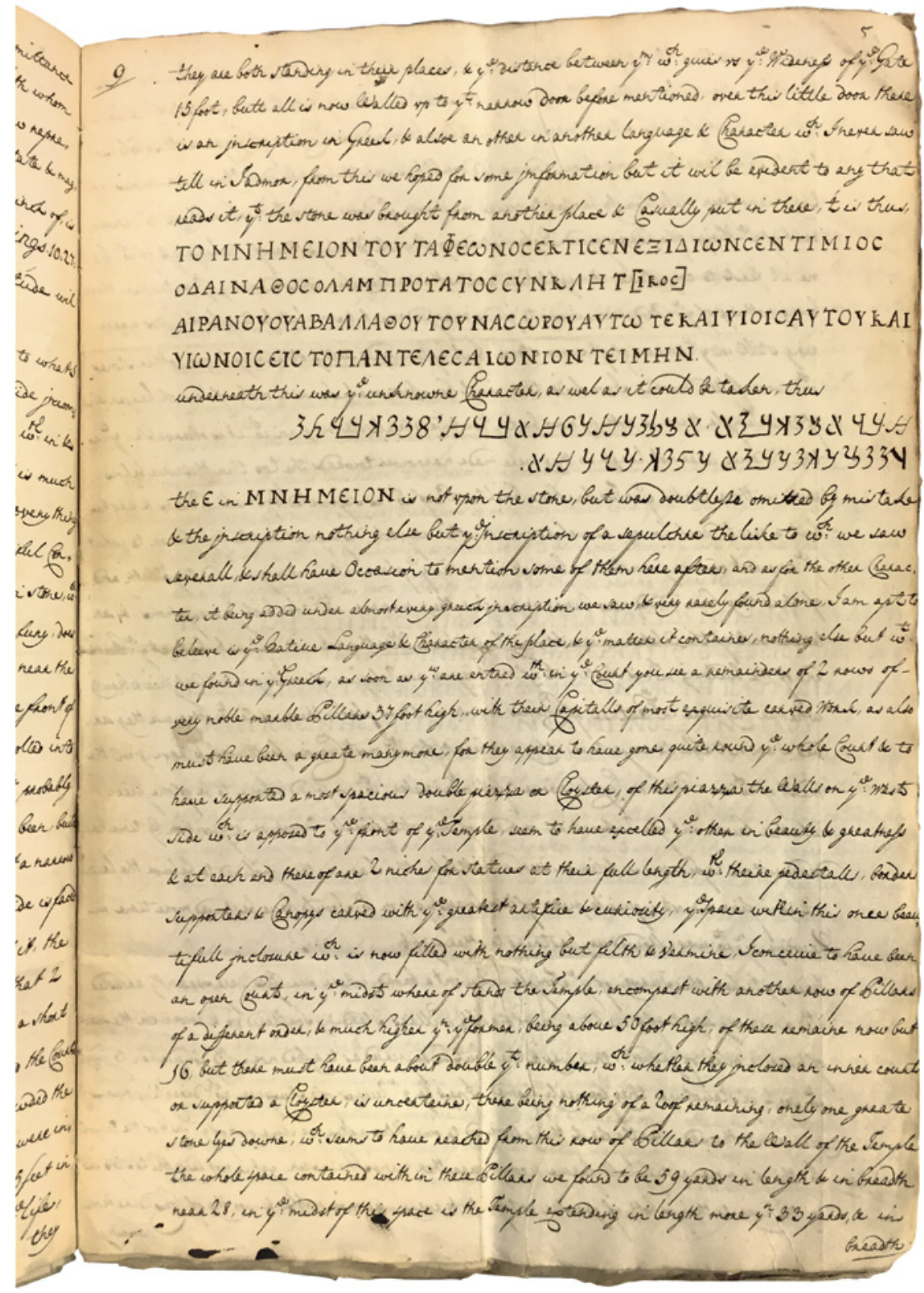

FIGURE 2.1 Palmyrene inscription, reproduced in a manuscript copy of the travel report written by the English discoverers of the ruins of Palmyra. The Hague, Koninklijke Bibliotheek, $\mathrm{MS}_{72} \mathrm{C}_{3}$ 


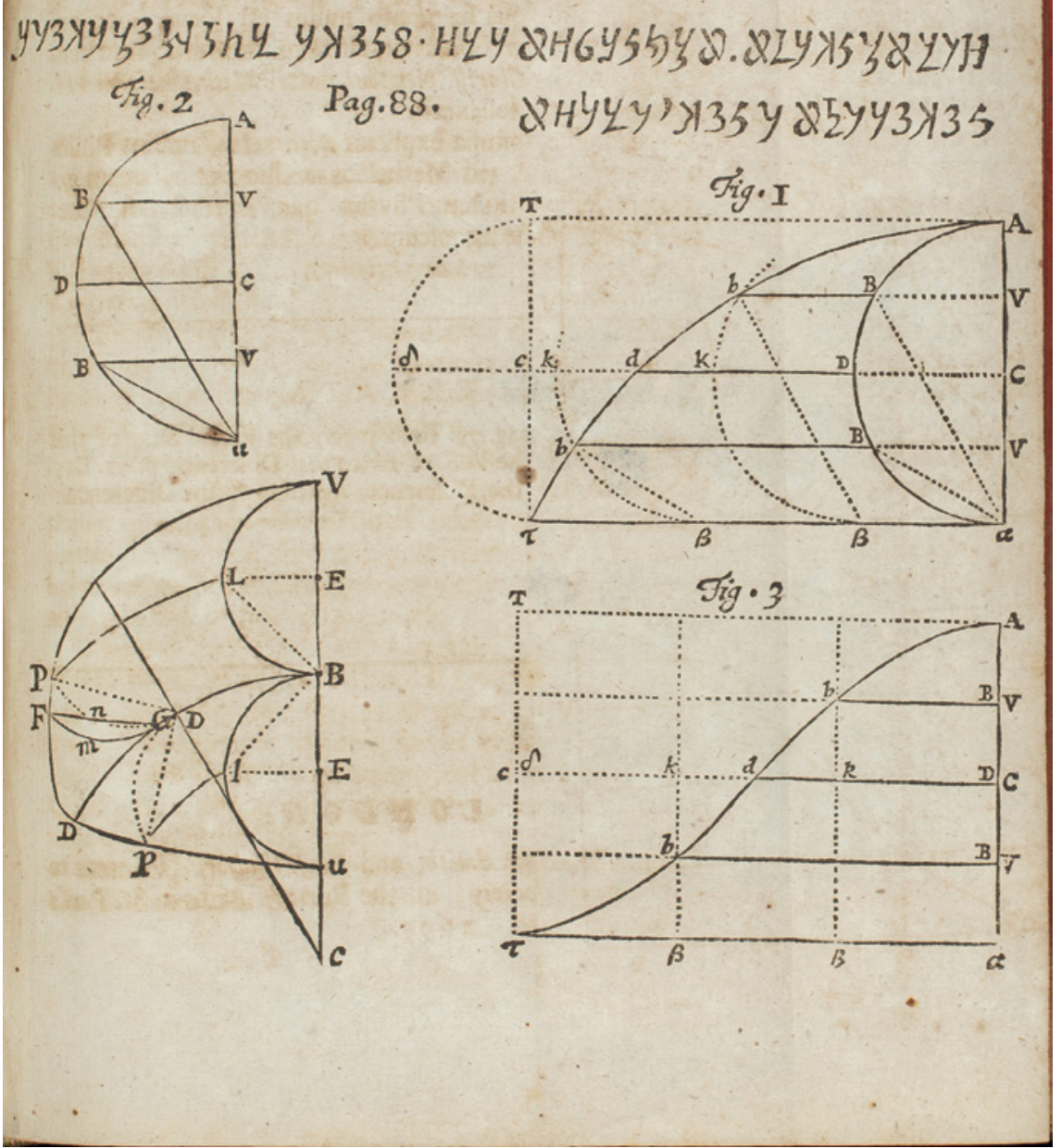

FIGURE 2.2 Palmyrene inscription, published in the Philosophical Transactions.

The Hague, Koninklijke Bibliotheek, call nr. KW 368 B 


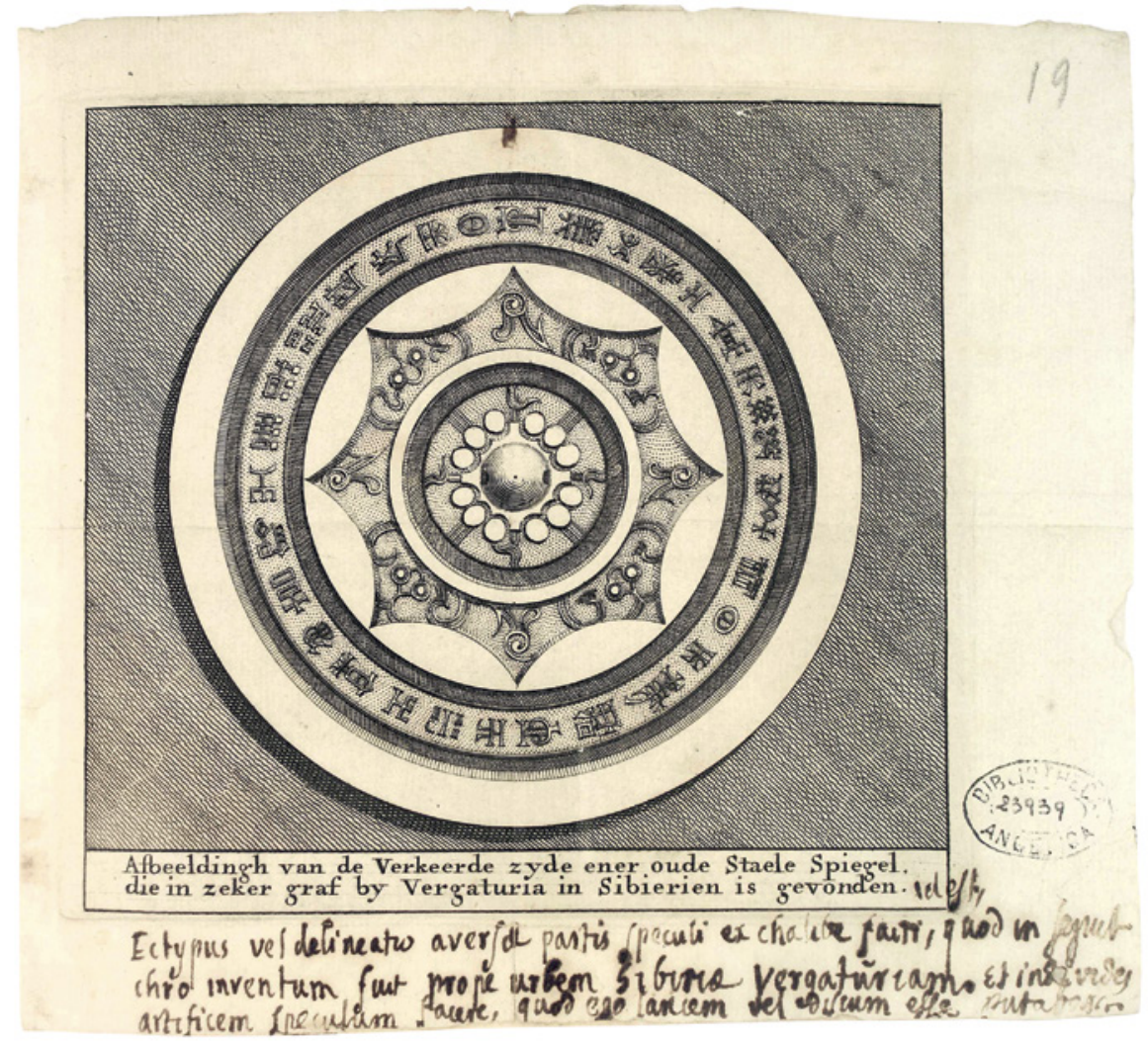

FIGURE 2.3 Ancient Chinese inscription, inscribed on a metal disc, reproduced in an engraving sent by Gijsbert Cuper to a correspondent in Rome. Rome, Biblioteca Angelica, MS 359

East India Company, sent him an artifact which originated in the Urals. Found in a Siberian grave, this circular, metal mirror had been engraved with ornamental patterns and a double row of Chinese characters on the rim of the disc (Fig. 2.3). It caused great excitement for Witsen and Cuper, as well as for several of their learned correspondents, since it appeared to be (and in fact was) a Chinese object of venerable antiquity, dating to before or around the beginning of the Christian Era. Jesuits had introduced the Chinese language to Europeans around 160o. In the Dutch Republic in particular, the study of Chinese took off after repeated visits to China by Nicolas Trigault SJ (15771628), successor to Matteo Ricci in the Jesuit mission there, and disseminator in Europe of the knowledge of China acquired by the missionaries. Throughout the seventeenth century, scholars reflected on the nature of the language, 
especially on the relation between written and spoken Chinese. The encounter with Chinese characters inspired speculations that universal pictography had engendered Chinese as well as Egyptian languages at a very early stage of human civilization. ${ }^{27}$

But this disc, of which Cuper received an engraving, with its old age and the characters that adorned it, was the most tangible source of information on ancient China that Europeans had yet laid hands and eyes on. ${ }^{28}$ Like the Palmyrene inscriptions, the Chinese mirror was a rare witness to a distant past. This artifact was all the more exciting because the disconcertingly old age of Chinese society, in particular, had anxiously been debated since the middle of the seventeenth century. In the years that followed, Cuper communicated with various scholars, in Berlin, Paris and Rome, about the Chinese characters. He came to know the thesis of John Webb (1611-74) that Chinese was the first language, spoken by Adam, and that possibly there was a connection between Chinese and ancient Egyptian. ${ }^{29}$ Cuper repeatedly asked his correspondents to keep him up to date, but he himself seems never to have committed to any of the theories circulating concerning the primacy of these ideographic scripts. ${ }^{30}$

Then samples of another type of ancient handwriting, causing as much amazement as the encounter with Chinese, began to circulate in Europe. The ruins of Persepolis had been attracting the attention of European travelers, mainly envoys to the court of the Persian shahs, since the beginning of the seventeenth century. The first descriptions of the cuneiform script appeared in travel accounts of Garcia de Silva Figueroa (1550-1624) ("characters composed of little triangles in the form of a pyramid") and Thomas Herbert (1606-82) ("figures, obelisk, triangular and pyramidicall yet in such symmetry and order

27 David E. Mungello, Curious Land: Jesuit Accommodation and the Origins of Sinology (Honolulu, 1989), pp. 13-20; Thijs Weststeijn, 'The Middle Kingdom in the Low Countries: Sinology in the Seventeenth-Century Netherlands,' in: The Making of the Humanities, ed. Rens Bod, Jaap Maat, and Thijs Weststeijn, 3 vols. (Amsterdam, 2010-14), 2: 209-41, there 210, 214-15.

28 The mirror has been studied with admirable breadth by Van Noord and Weststeijn, 'The Global Trajectory' (see above, n. 17). In what follows, my interpretation of Cuper's thoughts about China, Egypt, and biblical culture will deviate somewhat from theirs.

29 Letter of G. Cuper to M. V. de La Croze (9 August 1713), in: Gijsbert Cuper, Lettres de critique, d'histoire, de littérature, etc. écrites à divers savans de l'Europe, ed. Justinus de Beyer (Amsterdam, 1742), p. 140, where Cuper references John Webb, An Historical Essay Endeavoring a Probability that the Language of the Empire of China is the Primitive Language (London, 1669).

30 Weststeijn, 'From Hieroglyphs to Universal Characters' (see above, n. 5), pp. 249-54; Thijs Weststeijn, 'Vossius's Chinese Utopia,' in: Isaac Vossius (1618-1689): Between Science and Scholarship, ed. Eric Jorink and Dirk van Miert (Leiden, 2012), pp. 207-42. 
as cannot well be called barbarous"). Both De Silva Figueroa and Herbert suggested that even though it was impossible to decipher them, the cuneiform signs might bear some graphic relation to the ancient Hebrew and Greek alphabets. An engraved sample of cuneiform was first disseminated in Europe in the posthumously published second volume of the Viaggi (1658) of Pietro della Valle (1586-1652) (Fig. 2.4). ${ }^{31}$

Only a few scraps of cuneiform writing were available in print by the end of the seventeenth century. The inscription reproduced in Della Valle's Viaggi, for instance, consisted solely of five letters. André Daulier-Deslandes published a mere three letters in Les beautés de la Perse (1673). These small samples induced Thomas Hyde (1636-1703), the author of a book on Persian religion, to suppose that cuneiform was no script at all but merely a collection of ornamental devices. ${ }^{32}$ Seeing that so little cuneiform was actually available to examine, Cuper must have found it exciting to receive news about Cornelis de Bruyn (16521726/27). This artist had traveled extensively through the Middle East and South Asia in 1701-8. In Persia he had visited the ruins of Persepolis. Making elaborate drawings of the architectural remains he encountered, he took particular care to copy cuneiform script (Fig. 2.5). He also managed to gather some stone fragments and send them home. Cuper inspected both the copies and the original fragments himself in De Bruyn's home in Amsterdam in $1709 .{ }^{33}$ He asked for and obtained his own copies, which he distributed among his friends (Fig. 2.6). As with the other scripts, the Persian cuneiform elicited various responses from among Cuper's scholarly friends - about which more below.

In 1713 Cuper learned of an even more exciting inscription made up of unknown characters. The same Nicolaas Witsen who had shared the reproduction of the Chinese mirror with Cuper was in touch with Willem Konijn (fl. 1704-14), a prospective Reformed minister for whom he had procured a position on Ceylon (present-day Sri Lanka). Konijn had learned the local language, and Witsen suggested that Cuper send the prospective minister questions pertaining to the culture and nature of Ceylon. ${ }^{34}$ Cuper responded with

31 Quotations in Arthur J. Booth, The Discovery and Decipherment of the Trilingual Cuneiform Inscriptions (London, 1902), pp. 12-47. The engraving appeared in Pietro della Valle, Viaggi, 3 vols. (Rome, 1650-1658), 3: 286.

Eva Cancik-Kirschbaum and Grégory Chambon, 'Les caractères en forme de coins: le cas du cunéiforme,' Revue d'Assyriologie et d'Archéologie Orientale 100 (2006), 13-40, there $23-4$.

33 Jan Willem Drijvers, 'Cornelis de Bruijn and Gijsbert Cuper: A Skilled Artist and a Learned Discussion,' in: Through Travellers' Eyes: European Travellers on the Iranian Monuments [Achaemenid History 7], ed. Heleen Sancisi-Weerdenburg and Jan Willem Drijvers (Leiden, 1991), 89-107.

Letter of N. Witsen to G. Cuper (1 August 1712), U BA, MS Bf 60 (see above, n. 1). 
286

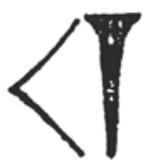

Letieria is. da Sciráz
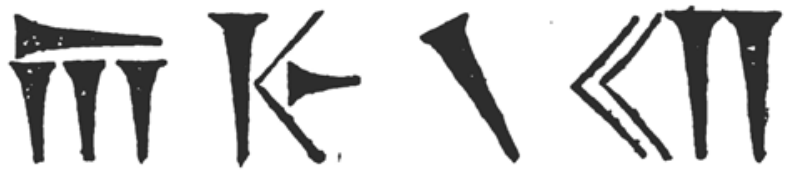

Mi dà inditio, che pofla fcriuerfi dalla finiftra alla deftra al modo noftro, il fecondo carattere, che è compofto di quattro figure fimili piramidali, trè diritte, con la panta in gitus \& vina fopra colcata. Perche, delle figure piramidali, il capo, in quefta fcrittura, come fi vede in tutti i caratteri, è la parte larga, che fempre ftà di fopra, quando ftan diritte. Hora, in quella figura piramidale colcata fopra te trè che ftanno in piedi, effendo il fuo capo, che è harte larga, alla finiftra, $l_{2}$ coda, che è la punta, alla deftra ; mo. itra, che il principio della fcrittura è dalla parte finiftra verfola deftra: turtauia, non l'affermo per lícuro. Il medefimo par che accenni il caraetere quarto di vna fola figura piramidale pendente; la cui parte fuperiore larga, che, come hò detto, è il fuocapo, ftà pur alla parte finiftra, e la coda, ò punta, verfo la deftra fi ftende. L'ifteffo anco fa , la piccola piramide di mezo, nel carattere terzo. Et a chi diceffe, che il capo, e'l principio delle piramidi. foffe la punta fottile, e non la parte larga i onde ii haueffe a prefumere il contrario: rifponderei, che bifognerebbe dunque, che nel carattere fecondo, \& in tutti gli altri, le piramidi haueffero la punta in sù, e no:2 in giù, conje Gi vede ausenire : perche in tutri $i$ caratteri di qualfiuoglia. forte, il capo, e'l principio loro, if ftima fempre la parte più alea, e non mai la più baffa. Pur, in fatti, fon mie fpeculationi, con nieare di certezza ; e può effer, che fia ałtrimenti. Notai di pià, che tutti i caratteri di quefta lcrierura fon compotti delle medefime figure piramidali, e di quelle altre più fottili angolari, variamente difpofte fià di loro; facendofi differenti i catarteri, vn dall'altro, folo nel numero, e nella difpofitsone, delle già dette figure. Do po le ifcrittioni, da vna banda e dall'altra della facciata, comincia fubito la proceflione delle ftatuette di baflo rilieuo, 


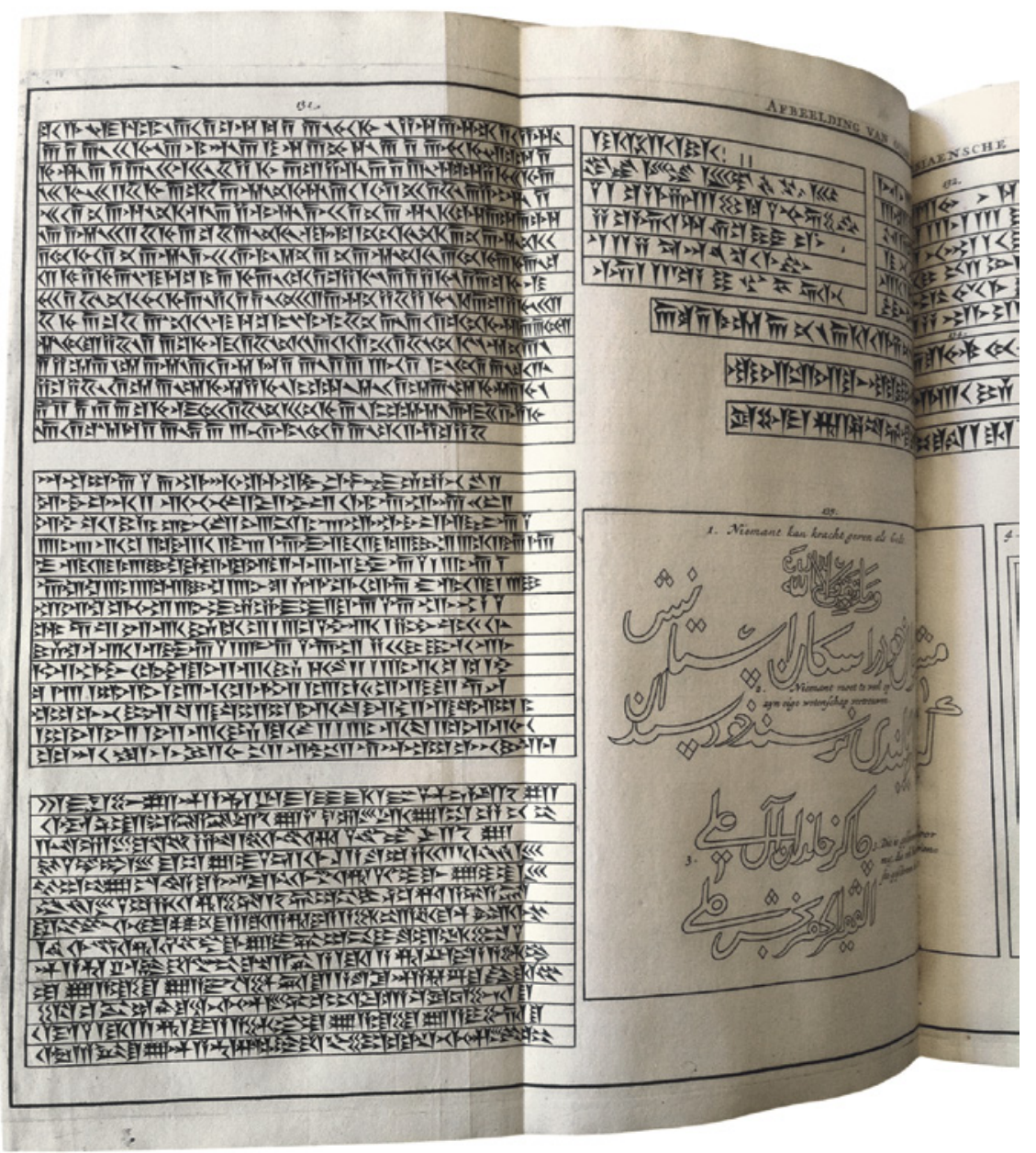

FIGURE 2.5 Cuneiform inscriptions in Persepolis, reproduced by Cornelis de Bruyn in his Reizen (Delft, 1698). Amsterdam, Rijksmuseum, call nr KOG OG 1

the questionnaire cited at the start of this article. The island was of interest to Cuper, since he saw possible connections to both biblical and classical culture. It might be identified as Taprobane, mentioned by the ancient author Diodorus Siculus (Bibliotheca Historica). Alternatively-or concurrently-it might also be the biblical land of Ophir (or part of it), the destination of the ships that King Solomon sent out to fetch gold (1 Kings 9,26-28). ${ }^{35}$

35 Letter of G. Cuper to N. Witsen (19 August 1712), UBA, MS Be 61 (see above, n. 1); letter of G. Cuper to N. Witsen (14 August 1713), U BA, MS Be 74a (see above, n. 1). Marion Peters has 


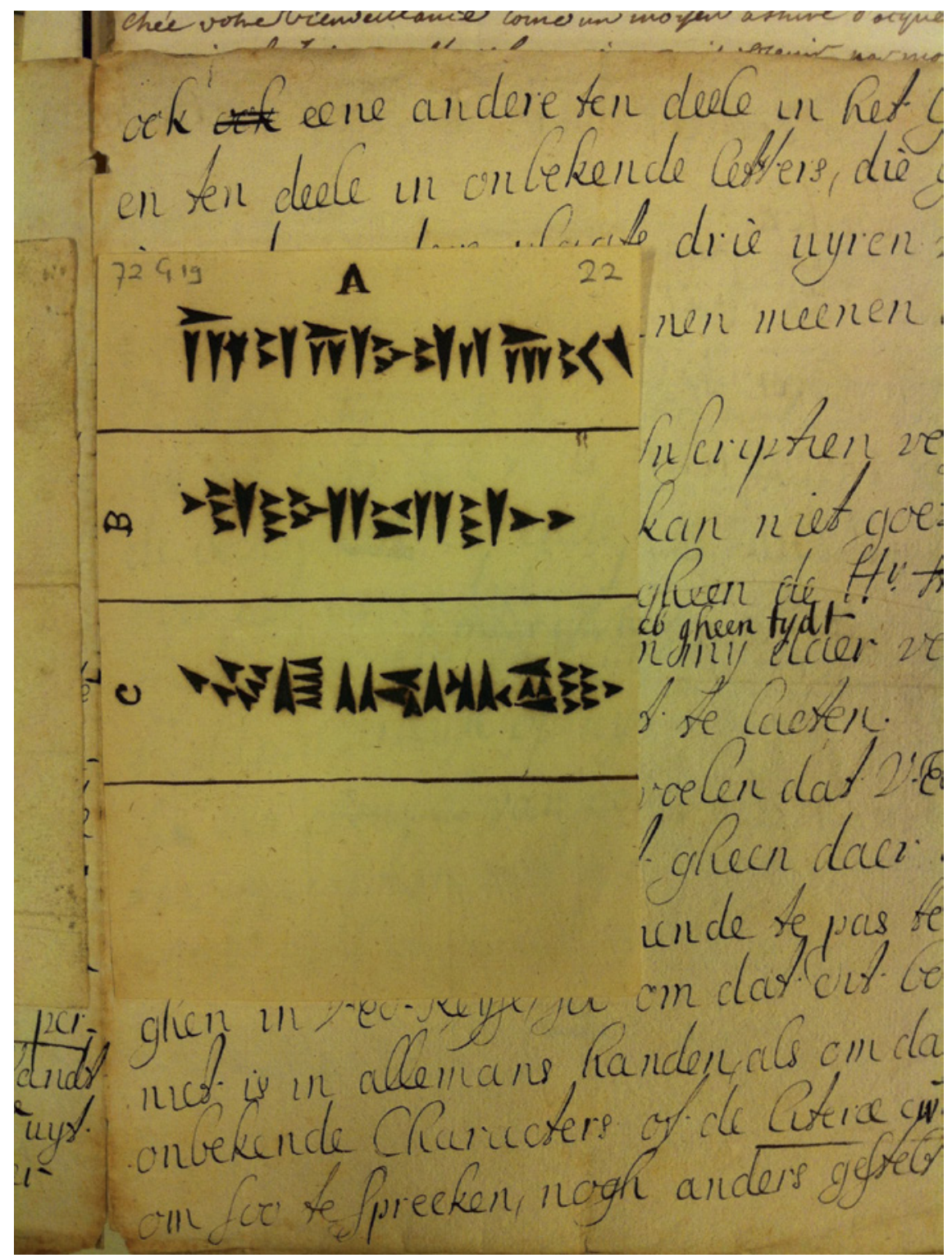

FIGURE 2.6 Sample of cuneiform, copied in ink by Cornelis de Bruyn for Gijsbert Cuper. The Hague, Koninklijke Bibliotheek, MS 72 G 19 


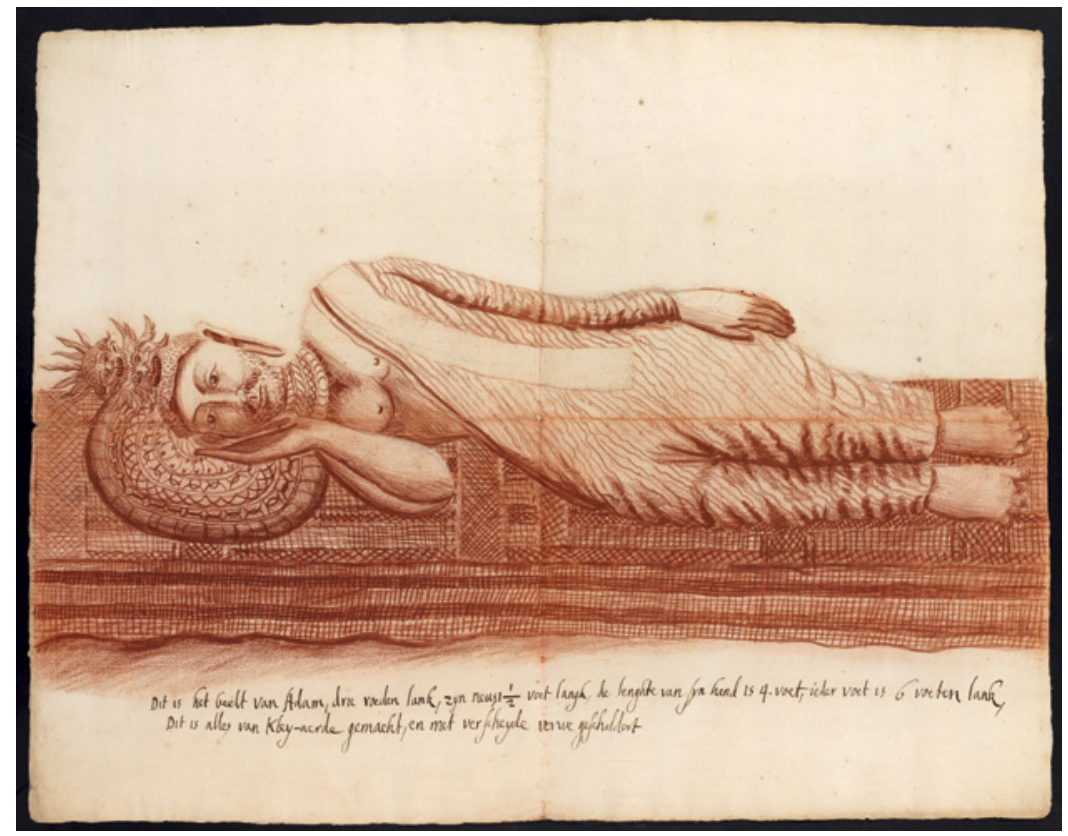

FIGURE 2.7 A statue of the reclining Buddha, in the cave complex in Mulgirigala, Sri Lanka, drawn in ink on paper. Amsterdam, University of Amsterdam, MS Bf 71 a

Cuper received from Witsen drawings and descriptions of an ancient religious site that the Dutch called Adam's Hill, in Mulgirigala, in the south of Ceylon. ${ }^{36}$ Adam's Hill is a large complex of cave sanctuaries containing enormous statues of human figures (Fig. 2.7) (Fig. 2.8) (Fig. 2.9). The figures in the temples hewn out of the rock of Adam's Hill are easy to recognize as Buddhas in various conventional poses (sitting cross-legged, sitting on the naga-throne, reclining). ${ }^{37}$ When Cuper received the material from Witsen, however, he

already noted Cuper's interest in Ceylon, including his initial intuition that it might have been mentioned in ancient writings (even though she has conflated the classical and the biblical traditions): Peters, 'Nicolaes Witsen and Gijsbert Cuper' (see above, n. 16), 132-3, 136-7.

36 Letter of N. Witsen to G. Cuper (17 September 1713), UBA, MS Bf 71a,c,d (see above, n. 1).

37 R. K. de Silva and W. G. M. Beumer, Illustrations and Views of Dutch Ceylon, 1602-1796: A Comprehensive Work of Pictorial Reference with Selected Eye-Witness Accounts (London, 1988), pp. 189-201. 'Adam's Hill' is not to be confused with 'Adam's Peak' or Sri Pada, a mountain with a giant footstep on top, attributed by Buddhists to Buddha and by Muslims and Christians to Adam. For the traditional Sinhalese poses of Buddha images: ibid., p. 472. 


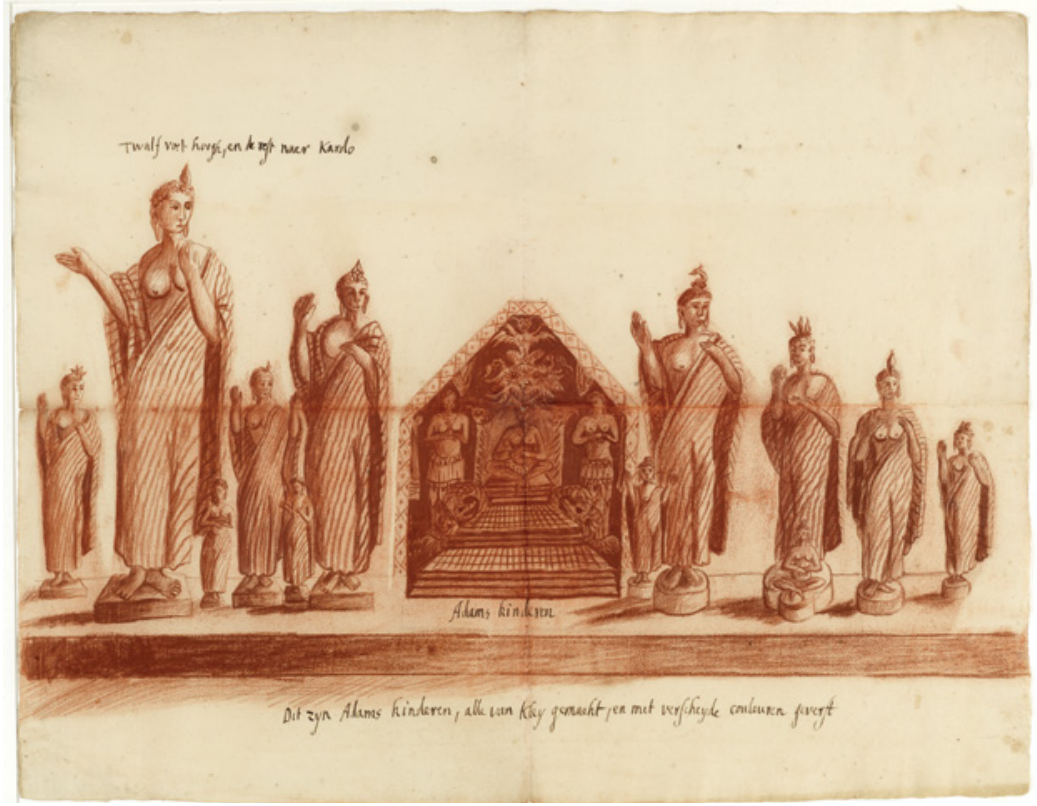

FIGURE 2.8 Various statues of the Buddha, in the cave complex in Mulgirigala, Sri Lanka, drawn in ink on paper. Amsterdam, University of Amsterdam, MS Bf 71c

understood them to be statues of Adam and Eve, marking the graves of the first human beings (see the next section).

On the steep way up to the statues there are, again, intriguing inscriptions. One is now considered to be a twelfth-century text in Sinhalese, giving the ancient name of Mulgirigala as Muhundgiri. ${ }^{38}$ This inscription, found in a rainwater basin on the plateau giving access to four cave temples, was rendered as a set of scribbles on the drawings that Witsen sent to Cuper in September 1713 (Fig. 2.10). ${ }^{39}$ Two years later Cuper received Konijn's copy of a Mulgirigala inscription, drawn with much greater care (Fig. 2.11). Even though it gives the impression of having embellishments originating in the draughtsman's fantasy, the characters are plausibly based on actual medieval Sinhalese script. ${ }^{40}$ An impor-

38 S. Paranavitana, The God of Adam's Peak (Ascona, 1958), p. 22.

39 Drawing accompanying the letter of N. Witsen to G. Cuper (17 September 1713), UBA, MS Bf ${ }_{71 g}$ (see above, n. 1). Cf. De Silva and Beumer, Illustrations and Views (see above, n. 37), p. 471.

40 Letter of W. Konijn to N. Witsen (2o November 1714), accompanying the letter of N. Witsen to Cuper (4 September 1715), UBA, MS Bf goc (see above, n. 1). It seems that Cuper had 


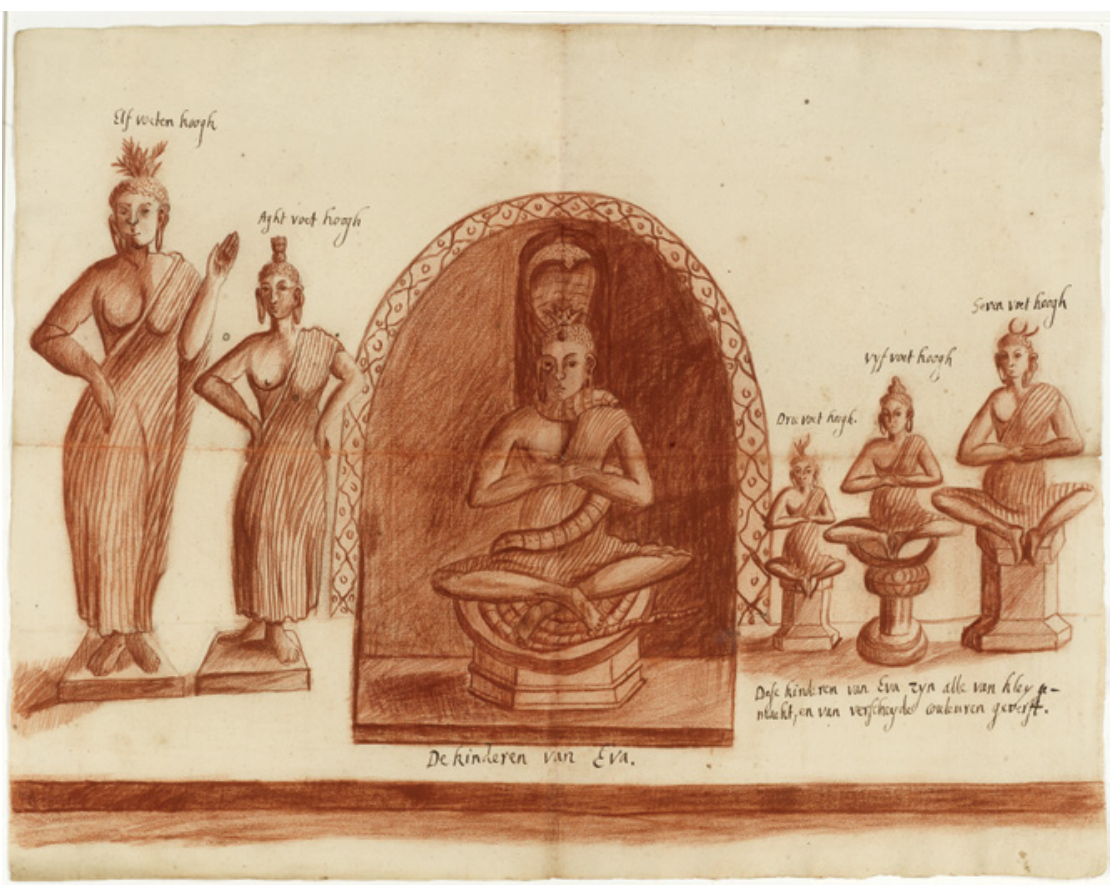

FIGURE 2.9 Various statues of the Buddha, including a Buddha sitting on the naga-throne, in the cave complex in Mulgirigala, Sri Lanka, drawn in ink on paper. Amsterdam, University of Amsterdam, MS Bf 71d

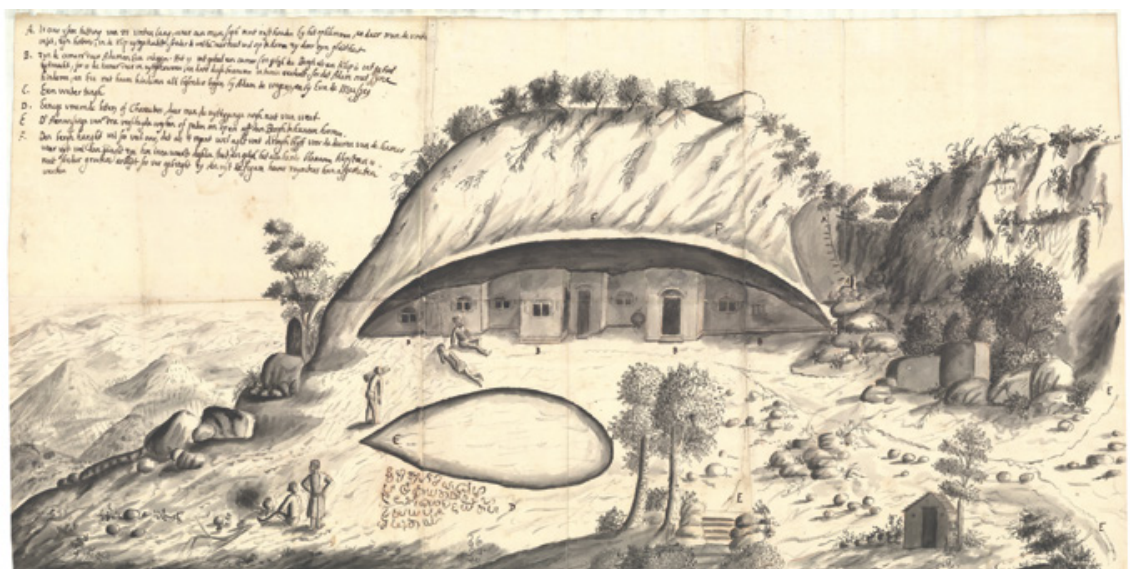

FIGURE 2.10 Part of the cave complex in Mulgirigala, Sri Lanka, drawn in ink on paper. Amsterdam, University of Amsterdam, MS Bf $71 \mathrm{~g}$ 


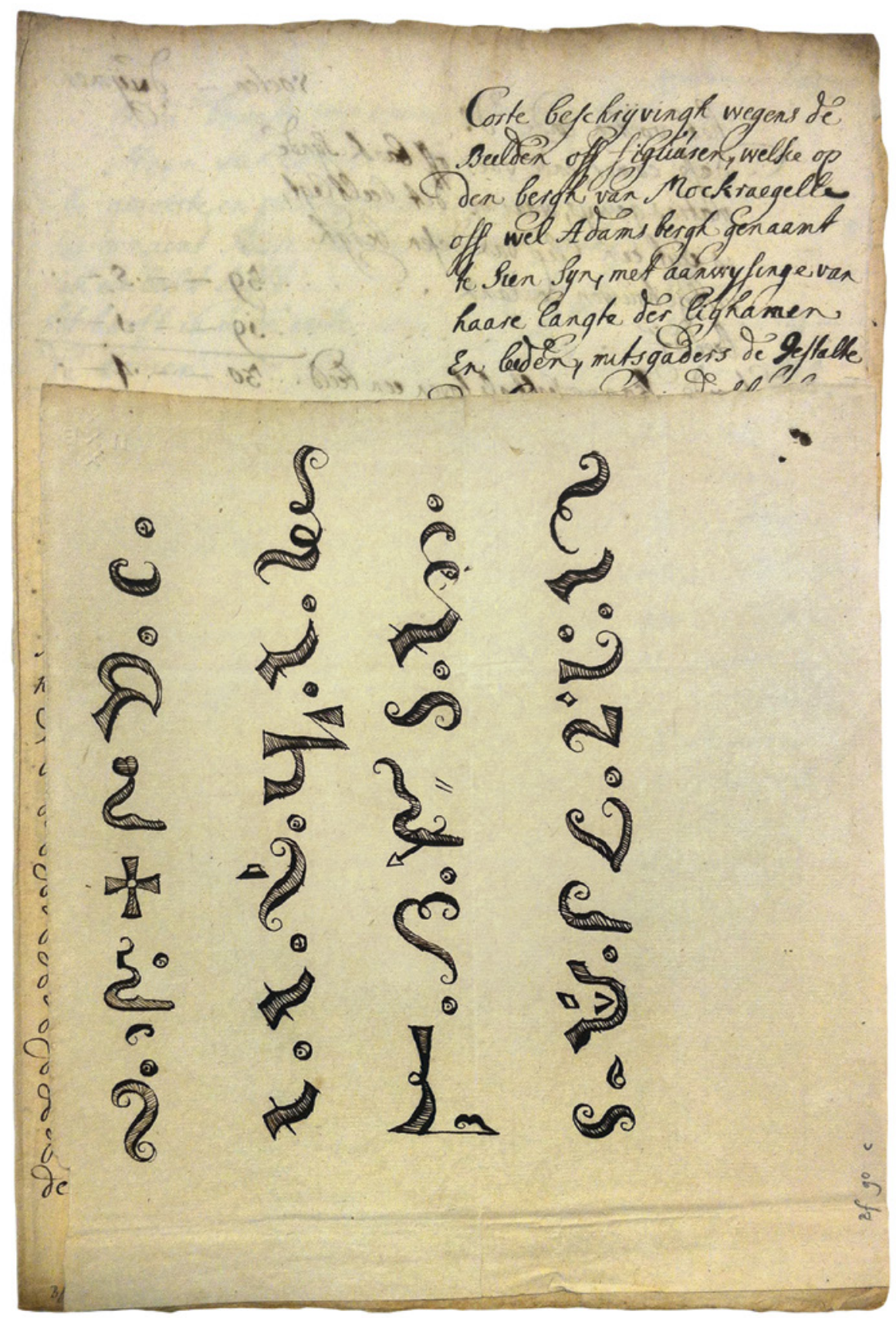

FIGURE 2.11 Sinhalese inscription, reproduced in manuscript by Willem Konijn, 1713. Amsterdam, University of Amsterdam, MS Bf goc 
tant feature of these engraved letters is that they were, like the Chinese characters on the Siberian mirror, ancient. Konijn could not find anyone in Ceylon who knew how to translate the characters. He associated them with the remains of stone settlements, which he surmised had been built by a people inhabiting the island long before the current population had established itself there. ${ }^{41}$ Cuper was impressed with the apparent obliteration of any memory of the script:

I also add the inscription [i.e., returning it to you] that has been carved in a rock on the aforementioned mountain [i.e., Mulgirigala], and it is curious that nobody can explain it, which indicates that it has been made there by another people, or that the letters have at some point been changed and fallen into disuse. ${ }^{42}$

Cuper's intellectual horizons, it would seem, expanded substantially from about 1690, during the last twenty-five years of his life, with respect to the classical and biblical world with which he had grown up. This was due to his exposure to a bewildering variety of new texts and artifacts - the reproductions of inscriptions from across the Eurasian continent representing texts and artifacts at the same time. The inscriptions of which he received copies were all ancient, discovered at sites that contained the relics of bygone ages. With the acquisition of samples of ancient Palmyrene, Chinese, Persian, and Ceylonese writing, Cuper had scripts at his disposal which were sufficiently diverse to defy accommodation within his cultural framework, determined by Scripture and the classics. Tellingly, in 1714 and 1715, two years before his death, Cuper seems to have immersed himself in a collection of travelogues. In those years, the letters he wrote to Witsen dealt exclusively with the 28 -volume series published by Pieter van der Aa, Naaukeurige versameling der gedenk-waardigste zee en land-reysen na Oost en West-Indiën [Accurate collection of the most

already obtained another reproduction of the same inscription, probably in 1714: UBA, MS Bf $75^{b}$ (see above, n. 1). See, for a comparison with an actual twelfth-century Sinhalese inscription: G. S. Ranawella, ed., Inscriptions of Ceylon, 8 vols. (Colombo, 1970-2008), 6: 339. Unfortunately, I have neither been able to visit Mulgirigala nor to find a reproduction of the inscription in the basin in front of the Alut Viharaya and Naga Viharaya.

41 Letter of W. Konijn to N. Witsen (20 December 1714), accompanying N. Witsen to G. Cuper, 4 September 1715, U BA, MS Bf 90 (see above, n. 1).

42 "Hier gaet ook bij het opschrift, het welk in een rots gehouwen is op gemelten berg, ende het is verwonderinghs weerdigh, dat niemant die kan uijtlegghen, het welk een teken is, dat die daer gestelt is van andere volkeren, of dat die Characters t'eenemael verandert en uijt het gebruijkt geraekt zijn." Letter of G. Cuper to N. Witsen (1 October 1715), UBA, MS Be 92 (see above, n. 1). 


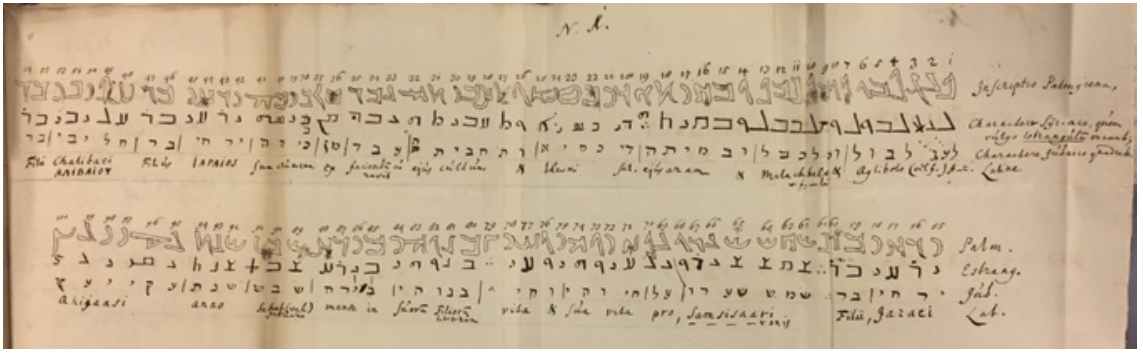

FIGURE 2.12 Palmyrene inscription, reproduced in ink by Jacobus Rhenferd, with corresponding characters in the Syrian Estrangulum-script and the common Hebrew Quadrata, and a Latin word-by-word translation. The Hague, Koninklijke Bibliotheek, MS 72 G 25

memorable voyages by sea and by land to the East and West Indies] (1707). ${ }^{43}$ The vastness of the world - culturally, rather than spatially-dawned on him in these final years of his life. It remains to be seen what consequences this new consciousness had for his awareness of the histories of writing, of human cultures, and of the adequacy of the biblical account in accommodating them.

Cuper was one of several European scholars whose encounters with previously unknown types of ancient writing left their mark on their conceptualizations of world history, and God's part in shaping it. As we observed above, Cuper was not proficient in any ancient language other than Latin and Greek. He seems never to have made any attempt to learn other ancient languages, either. If he articulated ideas concerning the relative antiquity and mutual relations of scripts, he did so based on their appearance, not on the languages they recorded. Accordingly, he made no attempt to decipher the scripts. This neglect of the phonetic or semiotic value of letters and characters is borne out by a mistake he made when passing on Rhenferd's first efforts to decipher the Palmyrene script to his Berlin correspondent La Croze. Rhenferd had sent him the inscription, with a tentative word-by-word translation in Latin written underneath the lines. Cuper sent along only a version of the Latin translation,

43 Naaukeurige versameling der gedenk-waardigste zee en land-reysen na Oost en WestIndien, 28 vols. (Leiden, 1707); Marion Peters, De wijze koopman: het wereldwijde onderzoek van Nicolaes Witsen (1641-1717), burgemeester en VOC-bewindhebber van Amsterdam (Amsterdam, 2010), pp. 282-3. 


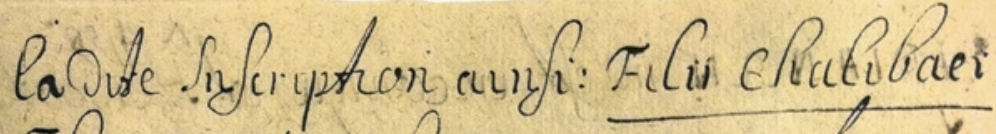

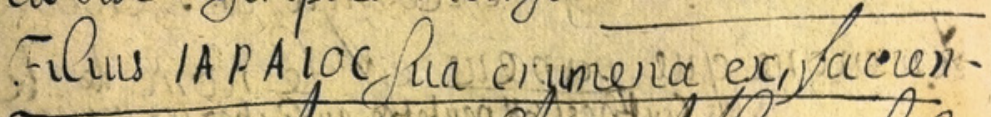

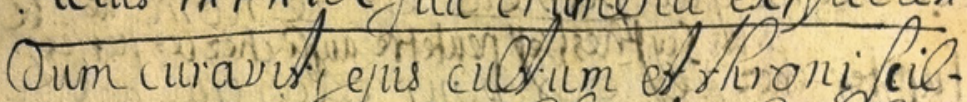

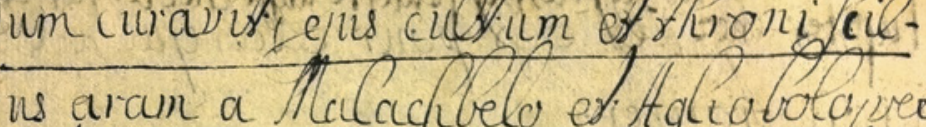

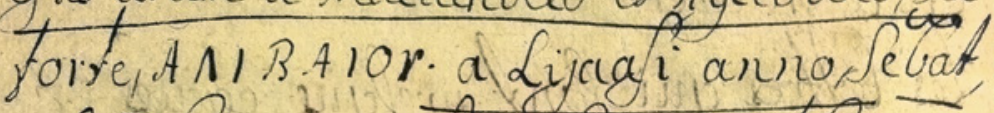

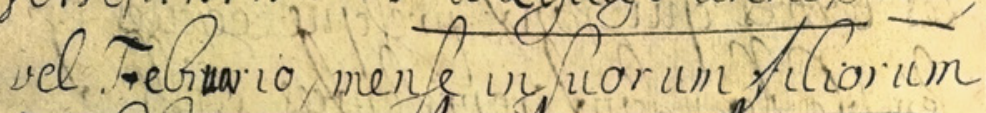

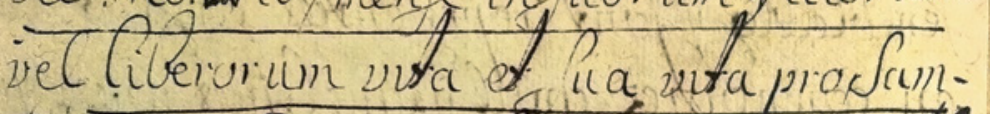

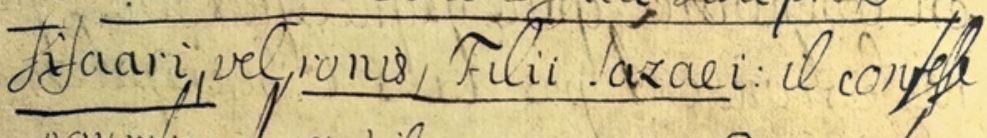

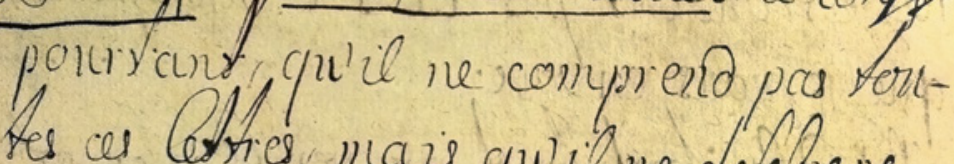
tes ces conves mais qui ine defepere pas den venir a coubres cosmiss quife

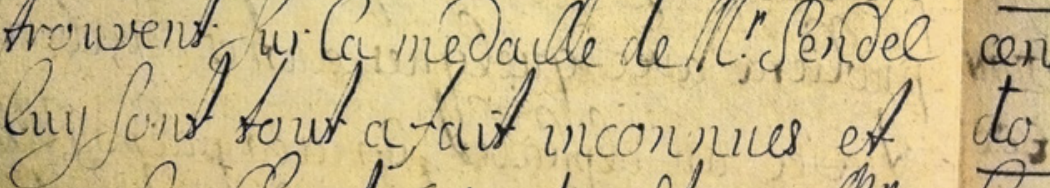

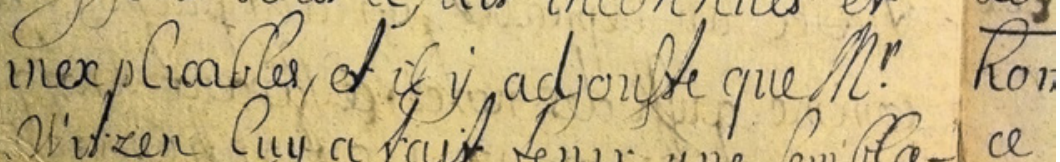

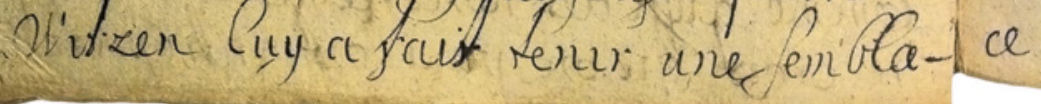

FIGURE 2.13 Draft of a letter of Gijsbert Cuper to Mathurin Veyssière de La Croze, reporting Rhenferd's word-by-word translation of the Palmyrene inscription. The Hague, Koninklijke Bibliotheek, MS $72 \mathrm{H} 18$

which, because he had not reversed the word order, produced an incomprehensible sentence (Fig. 2.12) (Fig. 2.13) ${ }^{44}$ He had forgotten that Semitic languages are written right to left instead of the other way around, as he explained in a subsequent letter:

44 Letter of G. Cuper to M. V. de La Croze (9 July 1709), KB, MS 72 H 18 (see above, n. 24). 
I made a laughable mistake, when I had the honour of sending you my last letter. No doubt you will have noticed this blunder, and I apologize for it. The fact is that copying out the explication that mister Rhenferd gives of the memorial inscription, to call it that, of two Palmyrene divinities, I started reading it from the left hand side to the right hand side, instead of what I should have done the opposite, as you will make out from what follows: [there follows the transcript of the Latin translation in the right order.$^{45}$

With regard to non-European scripts, and their origins, Cuper relied purely on visual reproductions, not on any linguistic referentiality.

At first sight this might seem to corroborate a seventeenth-century Dutch fascination with letters based on pictures of things, a pictorial ideographic script, as a more immediate form of written communication: a "general desire to sidestep the contingency of alphabetic signs and arrive at pure communication of knowledge," as Thijs Weststeijn puts it. This pictorial imperative supposedly was behind the evolution from fantastic theories about the semiotic richness of hieroglyphs to systematic attempts to construe graphic systems for the expression of logical relationships. ${ }^{46}$ Nevertheless, as we will see below (pace Weststeijn), despite Cuper's concentration on visual analysis, he and his contemporaries were very clear about the superiority of phonographic characters over ideographic characters-even if they differed about which of the two types of script they preferred to study.

Debate the origins of scripts Cuper certainly did, especially during the last decade of his life. The initial questions he raised with his correspondents were conventional. He wanted to know whether the study of scripts could help establish which alphabet had been the first. More specifically, he hoped that the primacy of either the well-known Quadrata Hebrew or the Samaritan script might be determined. The genealogy of scripts and languages was a fashionable topic in the decades around 1700, and several of Cuper's correspondents are known to have been prolific participants in these debates: Mathurin Veyssière de La Croze, Louis Bourguet (1678-1742), and Gottfried Wilhelm Leibniz (1646-1716).

45 "Incidi in ridiculum errorem, quand j'avois l'honneur de vous envoier ma derniere lettre. Vous l'aurez sans doute remarqué cette bevuë, et j'en demande pardon. Le factum est, qu'en copiant l'explication, que Mr. Rhenferd donne a l'Inscription conservatrice, pour m'exprimer ainsi, de deux divinitez Palmyrennes, j'ay commence, a la lire de la main gauche vers la droite, au lieu que je devois faire le contraire, comme vous verrez par ce qui s'en suit: [here follows the transcript of the Latin translation in the right order]," letter of G. Cuper to M. V. de La Croze ([before 7 September] 1709), KB, MS $72 \mathrm{H} 18$ (see above, n. 24).

Weststeijn, 'From Hieroglyphs to Universal Characters' (see above, n. 5), p. 240. 


\section{$5 \quad$ Ideography and Phonography}

In Cuper's correspondence, we see the various ways that intellectuals schematically related the art of writing to world history and to God's interventions in human affairs. One of the most significant exchanges was with La Croze. The librarian from Berlin was probably the most voracious linguist among these correspondents. He studied on average one language a year. He was also the most optimistic about the possibility of reconstructing a global linguistic genealogy that could accommodate all languages. With Leibniz, La Croze discussed the relation of Albanian to Russian, whether Armenian derived from the language of the ancient Medes, and, famously, whether Coptic was the key to Egyptian and Chinese characters alike. ${ }^{47}$

La Croze seems to have fit the identikit of the graphic idealist. He was concerned with a writing system common to all humankind. He considered ideographic characters (Egyptian, Chinese) to be much more ancient than phonographic ones (Hebrew, Greek), and more apt for a system of 'real characters' (signs denoting things rather than sounds or words), possibly even a universal writing system. He shared this framework with John Wilkins (1614-72) and Leibniz. ${ }^{48}$ Following in the footsteps of Kircher, La Croze was obsessed with finding the 'key' which would reduce ideographic scripts as diverse as ancient Egyptian and Chinese to a single graphic system (even though he was dismissive of Kircher's own attempts to arrive at such a key). He was convinced that the Coptic language would provide this key. ${ }^{49}$ Underlying this search for a universal graphic script implicitly is a Baconian ideal. A writing system that would convey meaning by picturing things directly would obviate the distorting effects of words. It would restore the universal accessibility that written communication had once possessed but had lost as societies in different parts of the globe-Egyptians, Chinese, the civilizations in Mexico-developed their cultural idiosyncrasies. ${ }^{50}$

47 Malte-Ludolf Babin, 'Armenisch, Albanisch, Hokkien ... Zum sprachwissenschaftlichen Teil von Leibniz' Korrespondenz mit Mathurin Veyssière de la Croze (1704-1716),' in: Einheit und Vernunft und Vielfalt der Sprachen: Beiträge zu Leibniz' Sprachforschung und Zeichentheorie, ed. Wenchao Li (Stuttgart, 2014), pp. 207-18. See for La Croze's attempt to derive the clavis sinica from Coptic: Stolzenberg, Egyptian Oedipus (see above, n. 5), pp. 228-9.

48 Jaap Maat, Philosophical Languages in the Seventeenth Century: Dalgarno, Wilkins, Leibniz (Dordrecht, 2004), pp. 10-23.

49 Letter of G. Cuper to M. V. de La Croze (19 July 1711), in: Cuper, Lettres de critique (see above, n. 29), p. 111; letter of G. Cuper to M. V. de La Croze ([after 21 August] 1713), ibid., p. 121.

50 Rossi, I segni del tempo (see above, n. 2), pp. 232-81; Maat, Philosophical Languages (see above, n. 48), pp. 10-12. 
Although enthusiastic about hieroglyphs and other ideographic writing systems, La Croze held the phonographic alphabet in even greater veneration. At a certain point, Cuper expressed skepticism that God had introduced Hebrew letters to the world when he had Moses inscribe them on the stone tables containing the Decalogue. ${ }^{51}$ La Croze responded with a passionate eulogy praising the divine splendor of the alphabet, resonant of Walton's essay in the London Polyglot. According to La Croze, the alphabet, "the wonderful art of dividing the voice into the imperceptible elements of which it is composed," was above the faculties of human beings to invent. He had always believed it to be a gift of God. ${ }^{22}$ In fact, precisely this supposed divine origin may have marked it as a static fact in 'early modern world history,' not prone to further investigationunlike the ideographic characters, created by human beings, which invited speculation about a diffusionist model of culture in which at least the entire Eurasian continent derived its pagan cultures from one single source.

A similar scheme - a phonographic alphabet given by God to Moses; ideographic characters much more ancient, of human invention, and possibly originating in one single source-was advocated by Louis Bourguet, a Swiss merchant and friend of Leibniz. ${ }^{53} \mathrm{He}$ even planned to write a book about the subject, a systematic account of the beginnings of writing (hieroglyphs), to be followed by sections on derivatives of the hieroglyphs, on Hebrew and related characters, on Greek and related characters, and thematic sections on writing's invention and the materials used for writing. The book has not materialized, but Leibniz could give Cuper a detailed table of contents. ${ }^{54}$

The graphic-idealist excitement about ideographic writing notwithstanding, La Croze's remarks about the divine nature of the alphabet should give us pause. They remind us that the providential scheme of early modern world history was affected by the origin of phonographic letters rather than that of Egyptian hieroglyphs and Chinese characters. Cuper, for one, did not share in the fascination with ideographic writing and the idea of its global diffusion from a single primeval culture-be that culture infantile or sage. From

51 Exo. 31,18; Exo. 32,15-6; Exo. 34,27-29; Deut. 5,22. In fact, the biblical text is equivocal about whether the inscription on the second set of Moses's tablets was physically written by God or by Moses.

$5^{2}$ “J'ai toujours cru jusqu'à present que Dieu qui a enseigné l'homme à parler, lui a aussi enseigné l'Ecriture. Quand je considère l'ars merveilleux qui divise si industrieusement les sons de la voix dans les élemens imperceptibles dont ils sont composez, il me paroit qu'il est au dessus de la portée de l'esprit humain d'avoir fait une telle découverte." Letter of M. V. de La Croze to G. Cuper (12 November 1710), KB, MS $72 \mathrm{H} 18$ (see above, n. 24).

53 Letter of G. Cuper to M. V. de La Croze (10 April 1714), in: Cuper, Lettres de critique (see above, n. 29), p. 144.

54 Letter of G. W. Leibniz to G. Cuper (29 December 1707), KB, MS $72 \mathrm{H}_{17}^{\mathrm{I}}$ (see above, n. 24), fols. $77 \mathrm{r}-84 \mathrm{v}$. 
the outset Cuper concentrated on Hebrew. He was convinced that the phonographic alphabet was older than La Croze allowed for-that is, older than Moses. Initially, Cuper deployed a biblical argument to push the invention of the alphabet back in time. In the books of Joshua and Judges, the Jews attacked the city of Qireyat-Sepher (City of Letters). If that city had already been called the 'City of Letters' before the Jews entered Canaan, then clearly the Canaanites had invented the alphabet themselves. ${ }^{55}$ But Cuper did not press the matter. He was politely noncommittal in his dealings with international scholars such as La Croze and Bourguet. However, in his protracted exchange with, for instance, Johannes Meyer (1651-1725), a little-known professor of theology at the University of Harderwijk, it is the phonographic Hebrew alphabet that he expressly inquired about. His much more outspoken statements in this correspondence show his conviction that the Hebrew alphabet was among the most ancient existing scripts, yet not necessarily the most ancient, and that several scripts may have come into use at different moments-implying that rather than a gift from God, they were the result of human inventiveness. ${ }^{56}$

Frequent encounters with exotic scripts after 1690 complicated matters. Cuper now had to deal with a variety of scripts that had come to his attention. The Palmyrene alphabet may not have caused too much of a disturbance. It was easily absorbed into the speculative evolution of Semitic scripts, as tabulated, for instance, by the Franeker professor Rhenferd. ${ }^{57}$ (Fig. 2.14) As for the Chinese of the Siberian mirror, Cuper did not give much credence to the diffusionist thesis. "I believe that neither the Egyptians, nor the Jews ever penetrated into China," as he put it in a letter to La Croze in 1708, in relation to the Chinese mirror discovered in the Siberian grave. ${ }^{58}$ Cuper duly forwarded reproductions of the ancient Chinese script, but he refrained from commenting on it himself.

It was Ceylonese culture which threw Cuper off balance. Attempts were already underway to find out whether contemporary Sinhalese, one of the living languages spoken on Ceylon, was related to any other language encountered in Eurasia. La Croze typically singled out words that Sinhalese seemed to have in common with Egyptian. This reflected his tendency to bring as many scripts

55 Letter of G. Cuper to M. V. de La Croze (15 October 1710), in: Cuper, Lettres de critique (see above, n. 29), pp. $75^{-6}$.

56 Letters of G. Cuper to J. Meyer (21 May 1709; 16 July 1709); 15 October 1709), KB, MS 72 G 18 (see above, n. 24).

57 Correspondence between G. Cuper and J. Rhenferd, KB, MS 72 G 25 (see above, n. 24), fol. 10or.

$5^{8}$ "Je croi che ni les uns [i.e., Egyptians] ni les autres [i.e., Jews] n'ont jamais pénétré jusques dans la Chine, ou dans la Siberie," letter of G. Cuper to M. V. de La Croze (4 December 1708), in: Cuper, Lettres de critique (see above, n. 29), p. 19. 


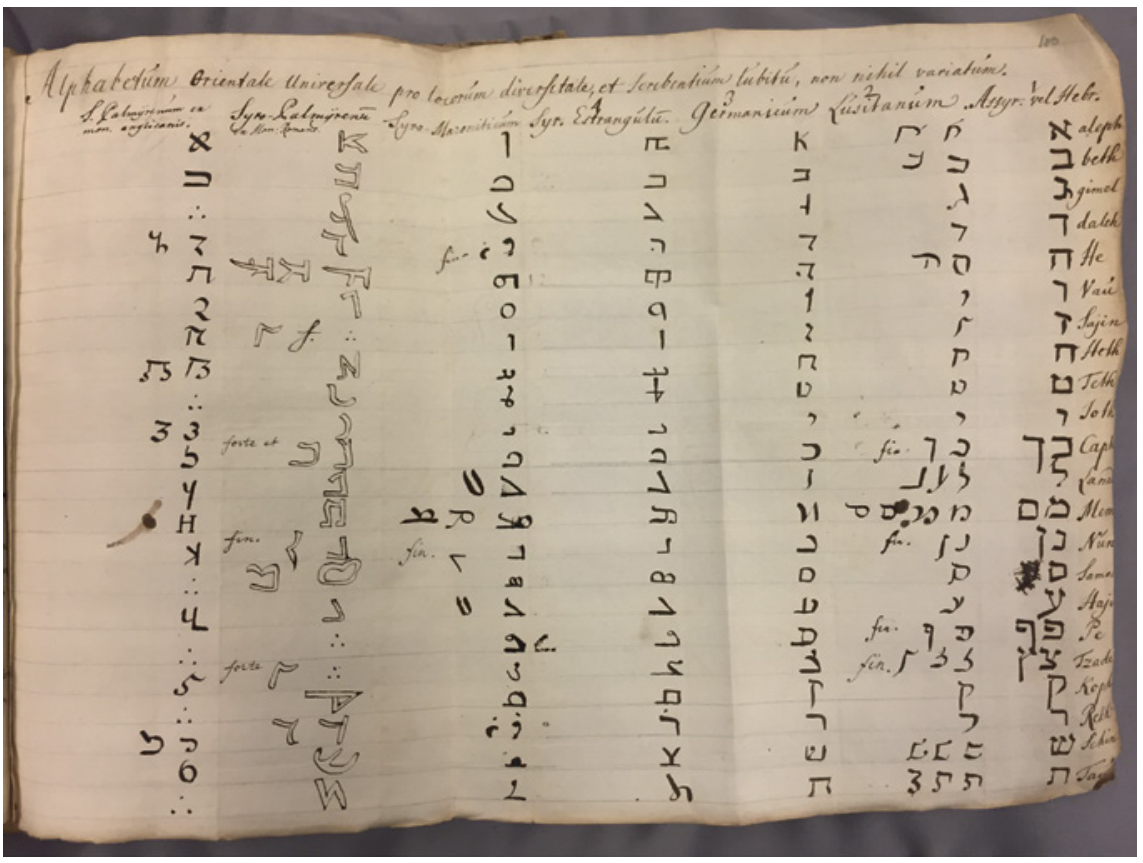

FIGURE 2.14 Semitic alphabets, tabulated by Jacobus Rhenferd. The second column has the Palmyrene alphabet. The Hague, Koninklijke Bibliotheek, MS 72 G 25

as possible within a globally diffused system of ideographic characters, which purportedly had devolved into a plethora of different sets of characters. Cuper was impressed-but also cautious, as usual. "If you happen to have some time, you would oblige me more than I know how to express, by informing me which Sinhalese words you think are Egyptian in origin." ${ }^{99}$ Witsen's representative on the island, the prospective minister Konijn, had investigated whether Sinhalese showed any similarities with Hebrew or Greek. He had found only eight words that seemed similar to Greek words both in their consonants and in their meaning. ${ }^{60}$

But more thought-provoking than contemporary Sinhalese was the inscription copied at the Mulgirigala sanctuary, which seemed to go back to times

59 "Si vous aviez quelque temps vous m'obligeriez plus que je ne sçaurois vous dire de me faire part de quelques mots Singalois, que vous croyez être Egyptiens." Letter of G. Cuper to M. V. de La Croze (9 August 1713), in: Cuper, Lettres de critique (see above, n. 29), pp. 139-41.

6o Letter of W. Konijn to N. Witsen (2o December 1714), accompanying N. Witsen to G. Cuper, 4 September 1715, UvA, MS Bf goc (see above, n. 1); cf. Peters, 'Nicolaes Witsen en Gijsbert Cuper' (see above, n. 16), 125-6. 
immemorial-literally, since the indigenous inhabitants had no recollection of their significance, suggesting pre-Sinhalese origins. This obscure origin added considerably to their value as graphic witnesses to archaic world cultures. Would these characters prove the diffusionists right after all, even if the script diffused was not ideographic but phonographic?

What was more, on the island there were ruins of a city, with towers and gateways made of cut stones. The contemporary Ceylonese people did not practice masonry. The techniques evident in the ruins seemed to corroborate the suggestion that before the current population arrived, another people had inhabited Ceylon. These extinct or emigrated previous inhabitants must have produced the inscription at Mulgirigala. Could they have been Egyptians? Chinese? Jews? The cross sign among the characters of the Mulgirigala inscription, moreover, "embarrassed" Cuper, as he remarked to La Croze in a letter of 1714: was it a reference, proleptic or prophetic, to Christianity? ${ }^{61}$ The other artifacts found at the site of the inscription compounded Cuper's embarrassment. Mulgirigala was famous for its sculptures marking graves attributed to Adam and Eve. The caves were filled with statues that supposedly depicted Adam and Eve (in fact they are Buddha statues), each seemingly surrounded by different sets of children. This would mean that Adam and Eve had offspring with other partners, which in turn would be an unsettling confirmation of the infamous pre-Adamite thesis of La Peyrère ('pre-Adamites' having produced various children with Adam and Eve, respectively). Cuper dismissed this possibility outright as a pagan superstition, but the thought clearly disturbed him. ${ }^{62} \mathrm{~A}$ feature which struck him particularly was the statue of Buddha protected by the naga, a giant snake (Fig. 2.9), which Cuper hesitantly associated with the snake in Paradise tempting Eve: "a sign, so it seems to me, that those Heathens, who erected these statues, or had them made, were knowledgeable about the deplorable and sad fall of our first mother."63

Especially the combination of an inscription which confirmed the diffusion of the art of writing from a Mediterranean cradle to the outskirts of the world, and a context of artifacts which confirmed the existence of people before Adam, was a menacing prospect for the consistency of world history within a biblical framework. At what temporal distance from Cuper's age would this

61 Letter of G. Cuper to M. V. de La Croze (22 November 1713), in: Cuper, Lettres de critique (see above, n. 29), pp. 145-6; letter of G. Cuper to M. V. de La Croze (5 May 1714), in: Cuper, Lettres de critique (see above, n. 29), pp. 151-2.

62 Letter of G. Cuper to N. Witsen (10 October 1713), UBA, MS Be 75 (see above, n. 1).

63 "Een teken, naer mij het toeschijnt, dat die Heydenen, die dese beelden hebben opgerigt of doen maeken, kennisse hebben gehadt van den beklaeghlijcken en bedroefden val van onse eerste moeder." Letter of G. Cuper to N. Witsen (28 November 1713), UBA, MS Be 76 (see above, n. 1). 
diffusion have taken place? Who could these people who had transmitted written knowledge - and to whom the Bible made no reference - have been? Again, Cuper discussed the Ceylonese inscription with the polyglot La Croze. To no avail: La Croze considered the characters very pretty, but he had no clue how to decipher them or where to position them in the universal genealogy of languages and scripts. ${ }^{64}$

Fortunately for Cuper, soon afterwards he was able to observe a resemblance between these statues and Siamese sculpture, and to conclude - wrongly — that the Ceylonese inscriptions derived from Chinese. ${ }^{65}$ Nevertheless, this episode very clearly shows how the historical scenarios available to scholars interested in the history of human language and scripts were becoming unstable. The neat binary development of a phonographic script, divinely planted among Semitic ancestors and used for the Bible and subsequently for the classical corpus, and a family of ideographic scripts, originating among the Egyptians and diffused among heathens across the globe, was becoming untenable. The providential scheme of the generation of Walton was giving way to the open-ended scheme that we have seen fully developed in the generation of Jaucourt.

Reproducing and Examining Scripts

Here it is expedient to dwell briefly on the issue of the reproduction and examination of letterforms in this period. It is in these decades that we see a deep concern for the accuracy of graphic reproduction, embodied in the development of state-of-the-art techniques for transferring ancient letters, drawn and chiseled, onto paper. We may surmise that with regard to inscriptions comprising unknown letters, the accuracy of transcription was even more important than with Latin or Greek inscriptions. After all, the reader would not be able to resort to intuition in combining letters into words and sentences. Every single

64 Letter of G. Cuper to M. V. de La Croze (5 May 1714) (see above, n. 61); letter of M. V. de La Croze to G. Cuper (22 May 1714), KB, MS $72 \mathrm{H} 19$ (see above, n. 24). For the copy of the inscription in Mulgirigala that Cuper had obtained already in 1714, before receiving the one Konijn had sent to Witsen, and which Cuper discussed with La Croze and Jean-Paul Bignon (1662-1743), see above, n. 40.

65 Letter of G. Cuper to M. V. de La Croze (5 May 1714) (see above, n. 61); letter of G. Cuper to J.-P. Bignon ([after 5 May] 1714), Lettres de critique (see above, n. 29), p. 327. In the latter, Cuper mentioned Trigaut, cited in Kircher's China illustrata, who reported that the Chinese language had a cross to mark the number ten, which for Cuper resolved the issue of the significance of the cross in the Ceylonese inscription. The editor of the Lettres de critique dated this letter "February 1714," but since Cuper did not mention the Ceylonese inscription to Bignon until 5 May 1714 (ibid., p. 328), this date cannot be correct. 
line had to be carefully examined so as to allow the unknown script to be compared with other letterforms.

It would seem that the improvement in the graphic craft of reproducing letters (written or inscribed) accelerated over the course of the seventeenth century. An early standard collection of European Latin epigraphy, a point of reference for scholars throughout the century, was Janus Gruterus's two volume Inscriptiones antiquae, published in $1602-3 .{ }^{66}$ Despite its claim to have been true to the original letterforms, in general the twelve thousand inscriptions reproduced in the two volumes looked more or less the same. Only in relatively few instances was the actual appearance of the epigraphy presented by way of a graphic reproduction. ${ }^{67}$ By the end of the century, this working method had changed. Jean Mabillon (1632-1707) issued his De re diplomatica libri VI in 1681. This work included sixty tables with reproductions of ancient and medieval writing, as well as artifacts. Mabillon's monumental publication is renowned as a first attempt to systematize historical source criticism. ${ }^{68}$ Incidentally, it is also a landmark in the graphic reproduction of writing. Its author treated script as just another type of ancient artifact, which ought to be rendered faithfully in form as well as content.

Excitement about Mabillon's project is borne out by letters exchanged between Cuper and Antonio Magliabechi (1633-1714), the librarian of the Grand Duke Cosimo III (1642-1723) of Tuscany. Magliabechi told Cuper about Mabillon's "curious book" in 1679, two years before its appearance. Magliabechi himself had contributed to the project with samples of writing from two treasures of the Medici library: a copy of Virgil from late antiquity and an early medieval copy of the Justinian Pandects. ${ }^{69}$ Tellingly, he drew attention to the way he had crafted the reproductions, following the instructions of the Maurists: he had "copied, or better, traced" the lines of letters. They were not re-drawn by sight but were re-traced on transparent paper stretched out on top of the original. ${ }^{70}$ Mabillon's paleographic innovation, and Magliabechi's enthusiasm

66 Janus Gruterus, Inscriptiones antiquae totius orbis Romani, 2 vols. (Heidelberg, 1602-3).

67 William Stenhouse, 'Classical Inscriptions and Antiquarian Scholarship in Italy, 160o1650,' in: The Afterlife of Inscriptions: Reusing, Rediscovering, Reinventing \& Revitalizing Ancient Inscriptions, ed. Alison Cooley (London, 2000), pp. 77-89, there 80.

68 First edition, Jean Mabillon, De re diplomatica libri VI (Paris, 1681). I have consulted the edition (Paris, 1709). See also Gabrielle Bickendorff, 'Die Geschichte und ihre Bilder vom Mittelalter: Zur “longue durée" visueller Überlieferung,' in: Visualisierung und Imagination: Materielle Relikte des Mittelalters in bildlichen Darstellungen der Neuzeit und der Moderne, ed. Bernd Carqué et al., 2 vols. (Göttingen, 2006) 1: 103-52, there 128.

69 Mabillon, De re diplomatica (see above, n. 68), pp. 354, 357.

70 "Il Padre Mabillon, fà stampare in Parigi, un suo dotto, e curioso Libro, intorno alle Scritture di ciascun secolo, per conoscere le vere, dalle false, e[cc.] Inserirà in questo 
about it, indicate the importance attached to visual precision by Cuper's contemporaries. They applauded innovative techniques of graphic reproduction.

We see this enthusiasm for graphic accuracy interwoven with the discussions about the origins of letters. This is clear, for instance, in La Croze's comments on the inscription from Ceylon. Not only was he enthralled by their visual appearance, but he was also impressed by the quality of the reproduction. He had seen another version in a manuscript of the Royal Library in Berlin, which was not as well executed as Cuper's: "The inscription which you have sent me can be found here, as well, but poorly drawn: your copy seems much more accurate."71

Cuper himself employed a draughtsman to reproduce the antiquities he discussed with his international set of friends. As he explained to Rhenferd in 1702, he could send the professor more samples of the Palmyrene writing another time, "when the person who normally draws for me, is back in town."72 Apparently the scholar had an artist in regular service to reproduce the many inscriptions, coins, and reliefs that he discussed with his interested friends across Europe. It is not surprising, then, to see La Croze praising Cuper for the accuracy of the copies he sent him.

In one extraordinary episode revolving around the inscriptions from Palmyra, we see a scholar and an artist collaborating in copying an inscription so accurately that the resulting depiction showed even the cracks of the original. This endeavor was a direct consequence of Rhenferd's dealings with the Palmyrene language. Dedicated to mapping the history of Semitic languages and scripts, Rhenferd meticulously compared Hebrew and Aramaic letterforms, past and present. A sample of this interest, a table of versions of Hebrew and other Semitic scripts, can be found among Cuper's papers. Rhenferd reproduced variations that were not only chronological but geographical, such as those of Sephardic and Ashkenazi Hebrew, typically the variants that he would encounter in the Dutch Republic (Fig. 2.15). In fact, as an added note explains, Rhenferd had copied the Sephardic script himself "with a trembling hand."73 Again, Rhenferd draws attention to the appearance of the reproduction, in this case

suo Libro i primi due versi di molti insigni manoscritti, copiati, o per dir meglio, lucidati per l'appunto. Per tale effetto, gli ho mandati lucidati in tal maniera, i primi due versi delle famose Pandette, e del celebre manoscritto di Vergilio, che quà si trova." Letter of A. Magliabechi to G. Cuper (1679 Nov 1), KB, MS 72 D 10 (see above, n. 24), fols. 4-5.

71 "L'Inscription que vous m'avez envoiée s'y trouve aussi, mais fort mal representée: vôtre copie paroît bien plus exacte." Letter of M. V. de La Croze to G. Cuper (22 May 1714), KB, MS $72 \mathrm{H} 19$ (see above, n. 24).

72 Letter of G. Cuper to J. Rhenferd (16 November 1702), KB, MS 72 G 25 (see above, n. 24), fols. $7 \mathrm{r}-8 \mathrm{r}$.

73 Correspondence between G. Cuper and J. Rhenferd, KB MS 72 G 25 (see above, n. 24), fol. $87 \mathrm{v}$. 


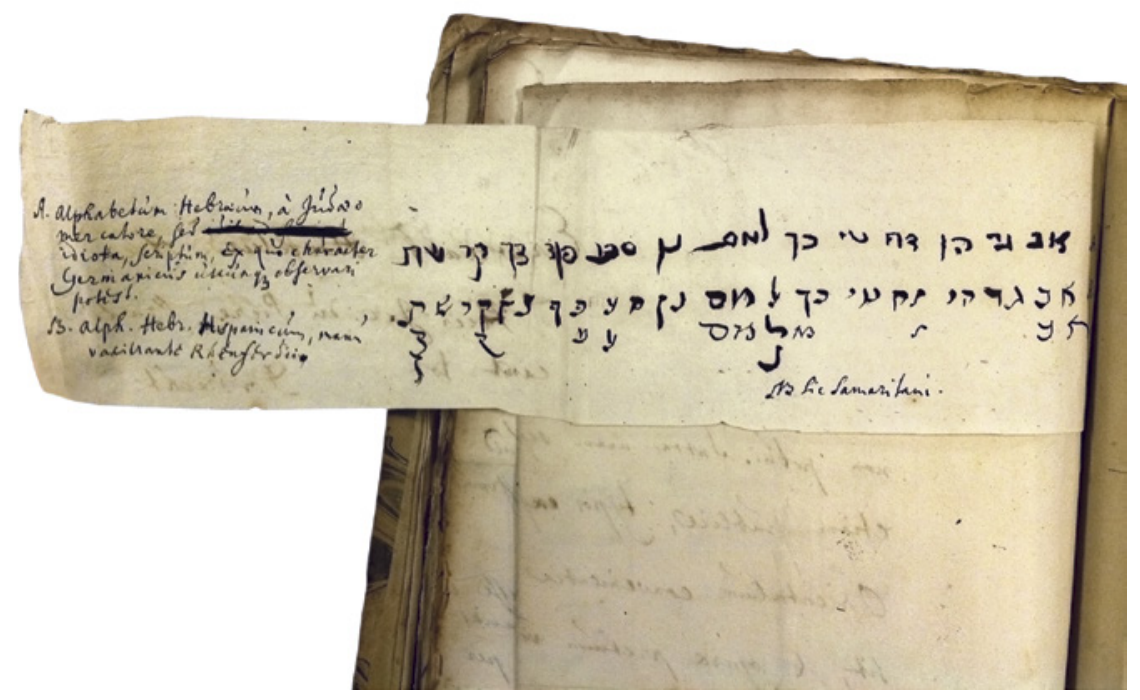

FIGURE 2.15 Sephardic and Ashkenazi variants of the Hebrew Quadrata, in a manuscript note of Jacobus Rhenferd. The Hague, Koninklijke Bibliotheek, MS 72 G 25

flawed because the effects of his illness threatened the meaningfulness of the copy.

Rhenferd and Cuper agreed that the inscriptions found by Halifax and his fellow travelers among the ruins of Palmyra had been printed poorly in the Philosophical Transactions of $1695 .{ }^{74}$ Following up on this, Rhenferd later approached Cuper for assistance in procuring another sample of the Palmyrene script. He noted that Gruterus's Inscriptiones antiquae, the standard publication on Roman epigraphy mentioned above, reproduced a stele found in Rome depicting the Syrian gods Aglibol and Malakbel. As recently as 1685 this reproduction from Gruterus had been republished in Jacob Spon's Miscellanea eruditae antiquitatis (Fig. 2.16) (Fig. 2.17). ${ }^{75}$ The relief featured a bilingual inscription, one in Greek, the other in letters that looked like Palmyrene. This constituted a vital resource for Rhenferd's study, a Rosetta Stone for the Palmyrene language, but unfortunately the printed reproduction was, again, inaccurate. He wanted a more precise copy and asked Cuper to mobilize his Roman network to obtain it.

74 "contuli literas Syriacas cum iis, quae editae sunt a Bernardo. animadvertique multum illas a se invicem discrepare." Letter of G. Cuper to J. Rhenferd (16 November 1702), KB, MS ${ }_{72} \mathrm{G} 25$ (see above, n. 24), fols. $7 \mathrm{v}-8 \mathrm{r}$.

75 Gruterus, Inscriptiones Antiquae (see above, n. 66); Jacob Spon, Miscellanea eruditae antiquitatis (Lyon, 1685), p. 1. 
After six years of frantic correspondence Cuper's attempts bore fruit. The famous antiquarian Francesco Bianchini provided Rhenferd with a copy of the inscriptions on the stele. Bianchini's report of his discovery of the inscription testifies to the pride he took in his meticulous method of working. The relief was built into the façade of the Villa Giustiniani in Rome and Bianchini had spotted it only by aiming his spyglass at the sculpture. He went to great lengths to produce a copy that would satisfy Rhenferd. He employed an "expert in the manufacture of models" to make the reproduction. The relief was situated high up in the façade, so Bianchini had the owners of the villa erect a scaffold for the artisan to stand on. The artisan covered the inscription with chalk. He made a mold by pressing the chalk into the cavities of the letters. He poured plaster over it, which hardened to a plaster cast. This cast allowed Bianchini to make a print of the inscription, on a large sheet of paper that ended up as foldouts in several manuscript volumes (Fig. 2.18). ${ }^{76}$ Bianchini was jubilant about its accuracy. One could see the letterforms, the distance between letters, and even the lesions! ${ }^{77}$

Bianchini's enthusiasm testifies to the concern for the actual, visual form of letters (alphabetic letters, not hieroglyphs or characters), analogous to Mabillon's novel technique. The almost obsessive investment in visual and graphic accuracy was certainly not unique to the study of scripts or of antiquities in general. In fact, the painstaking notation and depiction of visual minutiae was the hallmark of the naturalist counterparts to the study of antiquities - the study of minerals and fossils, of insects and plants, which were equally instrumental in a shifting hermeneutics. ${ }^{78}$ In the case of letterforms, however, higher accuracy did not lead to more clarity.

76 E.g. Correspondence between G. Cuper and J. Rhenferd, KB, MS 72 G 25 (see above, n. 24), fol. $142^{b i s}$; leaf accompanying the letter of G. Cuper to M. V. de La Croze (17 September 1709), KB MS $72 \mathrm{H} 18$ (see above, n. 24).

77 "Characteres quidem Graecos et Palmyrenos non satis distinguere dabatur nudis oculis, prae nimiâ scilicet altitudine, quae sexaginta palmorum intercapedine tabulam à me removebat. Optico tamen tubo eosdem ità secernebam, ut stylo imitari expeditè possem.... Quin etiam permiserunt, ut creta complanata admoveretur marmori per artificem plastices peritum: qui subinde lacunas $[\mathrm{sic}]$ characterum eandem adigens justo pressionis modo ectypon retulit: mox affuso supra cretam gypso toreuma literarum [sic] efformavit, archetypo quam simillimum: Unde ipse potui curare morosius ac reddere, singulorum characterum ductus, figuram, intervalla, et ipsamet vitia marmoris exesi, et in aes deinde transferri, ut inclusum exemplum ostendit." Letter of F. Bianchini to G. Cuper, undated [1708/o9], KB, MS 72 G 23/2 (see above, n. 24); the letter has been published in Francesco Bianchini, Opuscula Varia (Rome, 1754), pp. 55-9, with minor variants.

78 Eric Jorink, 'Between Emblematics and Argument from Design: The Representation of Insects in the Dutch Republic,' in: Early Modern Zoology: The Construction of Animals in Science, Literature and the Visual Arts, ed. Karl A. E. Enenkel and Paul J. Smith (Leiden, 


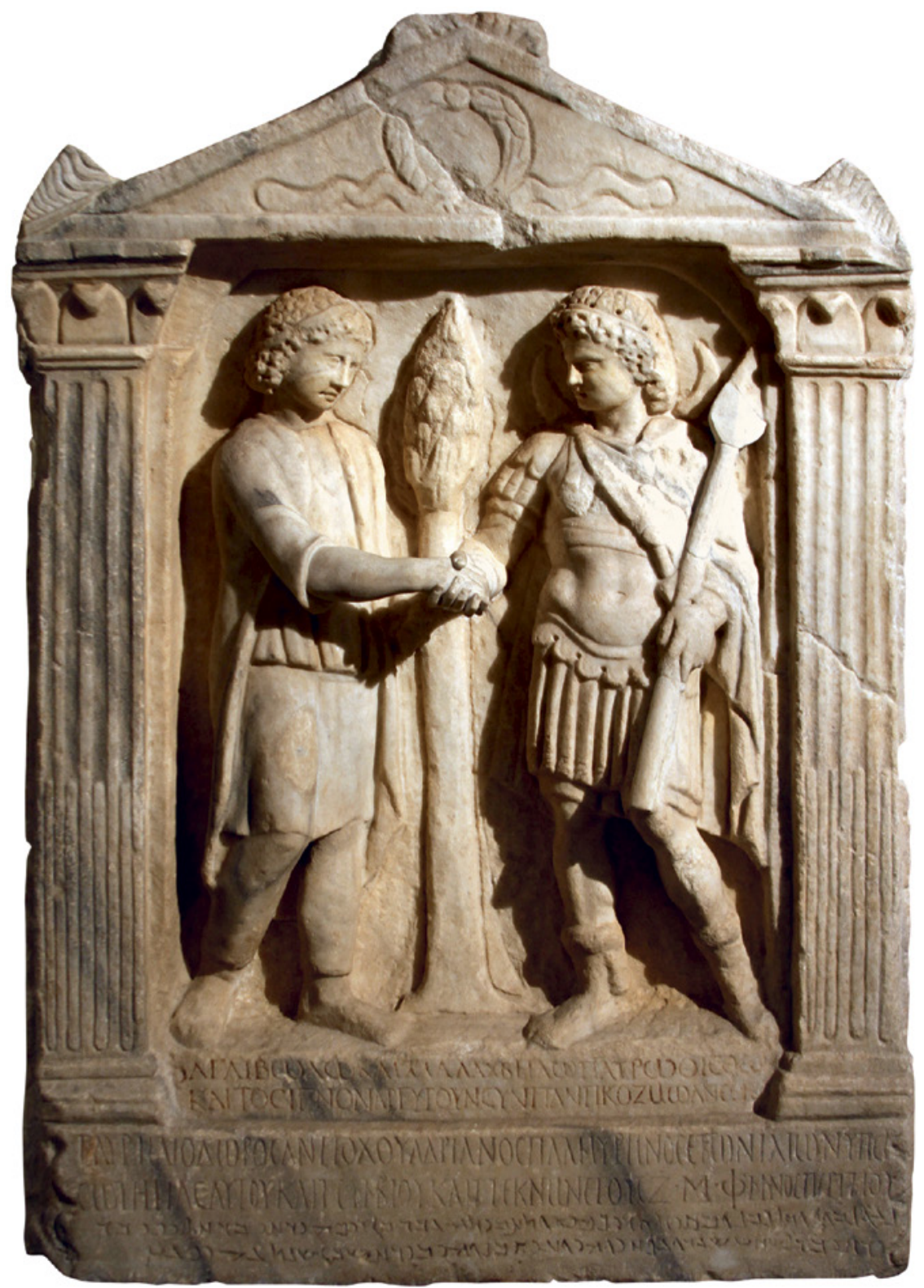

FIGURE 2.16 Syrian stele, found in Rome, with an inscription at the bottom in both the Greek and Palmyrene scripts. Rome, Capitoline Museum, NCE2406 


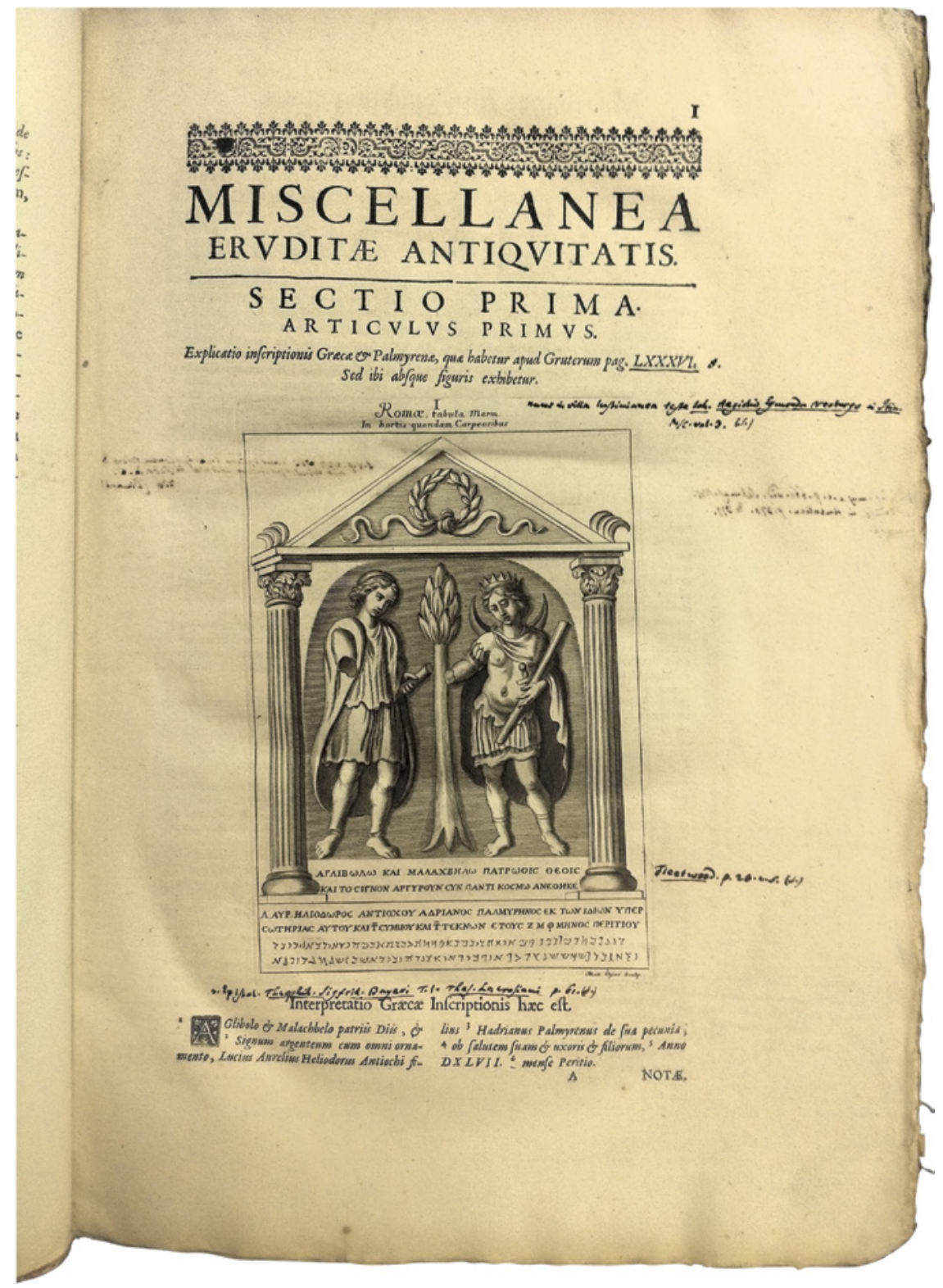

FIGURE 2.17 Syrian stele, reproduced in Jacob Spon, Miscellanea eruditae antiquitatis (Lyon, 1685), based on Janus Gruterus, Inscriptiones antiquae totius orbis Romani, 2 vols. (Heidelberg, 1602-3). The Hague, Koninklijke Bibliotheek, call nr. KW 392 C13 


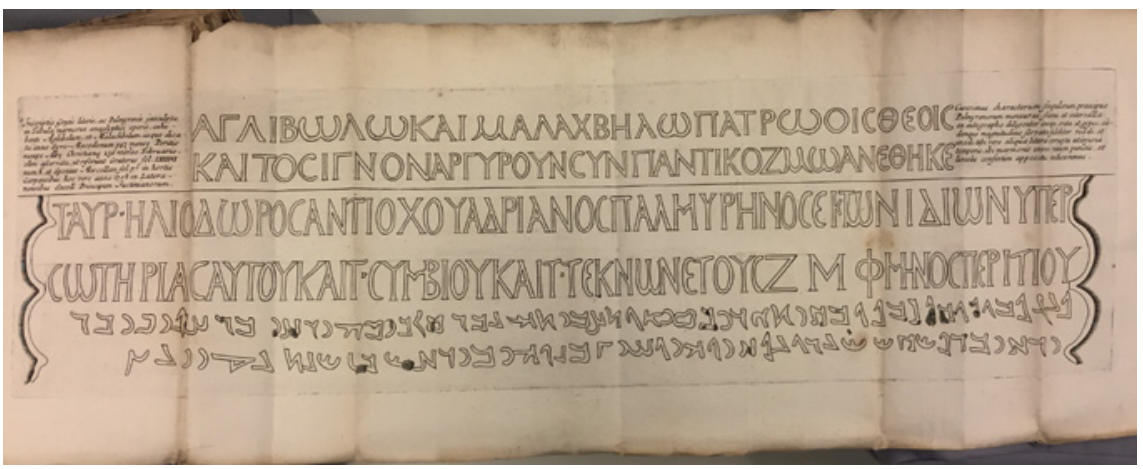

FIGURE 2.18 Palmyrene inscription on the Syrian stele, reproduced in engraving by the Utrecht printer Frans Halma, copy of Gijsbert Cuper. The Hague, Koninklijke Bibliotheek, MS 72 G 25

The care with which reproductions of unknown scripts were forged and examined was vital to the reception of these scripts and their accommodation in the perception of world history. Despite the ever-increasing accuracy of reproductions, formal relations among newly discovered scripts failed to reveal themselves, and their possible derivations from any of the others was not made clearer. Thus some scholars-including Cuper-became convinced that the history of writing did not reflect a gradual diffusion of graphically encoded wisdom from a single source, and that God had not created a Hebrew alphabet instantaneously as a unique stroke of genius for other cultures to follow. Rather, the application of ingenious principles had occurred in different places at different times by several cultures - at a remove that was distant and impossible to pinpoint exactly.

The factor of accurate reproduction was definitely in play in the evaluation of the significance of the cuneiform inscriptions found in the Middle East. When Thomas Hyde commented on cuneiform, he denied that it was even a script. The appearance of its signs had led him to this verdict: no single instance of a cuneiform sign occurred more than once, proving that these were not letters but merely ornamental elements. This hypothesis seemed to be corroborated by the fact that the signs he saw were separated by dots. This argument based on dots actually rested on a misperception, however: the dots had

2007), pp. 147-75; Paula Findlen, 'Agostino Scilla: A Baroque Painter in Pursuit of Science,' in: Science in the Age of Baroque, ed. Ofer Gal and Raz Chen-Morris (Dordrecht, 2013), pp. 119-59; Eric Jorink, 'Snakes, Fungi and Insects: Otto Marseus van Schrieck, Johannes Swammerdam and the Theory of Spontaneous Generation,' in: Zoology in Early Modern Culture: Intersections of Science, Theology, Philology, and Political and Religious Education, ed. Karl A. E. Enenkel and Paul J. Smith (Leiden, 2014), pp. 196-233. 
been added by one Samuel Flower (fl. 1693) to separate an arbitrary combination of several cuneiform letters which he raked together and depicted in an article in the Philosophical Transactions of $1693 .{ }^{79}$

Conversely, De Bruyn took care to reproduce the cuneiform with great technical precision. In a letter to Cuper of 1709 , Leibniz praised the artist for copying the Persian cuneiform so well. ${ }^{80}$ More generally, De Bruyn was renowned for the high quality of his depictions of artifacts. Zacharias von Uffenbach, who made a tour of the Republic in 1711, observed how De Bruyn executed his reproductions of antiquities on the spot:

He has made them after life, not only with Indian ink, but usually also with all kinds of water colors, and not only as mere designs, but he has always finished them on the spot, complete with foreground and embellishments. ${ }^{81}$

De Bruyn's reproduction of cuneiform prompted Cuper to look hard at these signs. In a letter to La Croze, commenting on the Persian script, Cuper responded to the former's predictable contention that the cuneiform letters were related to hieroglyphs - as were most scripts. Cuper failed to see anything hieroglyphic in them. The signs did not depict anything. Rather, they looked alphabetic, to be combined into words. ${ }^{82}$ On this point, Cuper agreed with Leibniz. In fact, the German philosopher was very impressed by the cuneiform script, by its form as much as its apparent antiquity. In a letter of 1707, he emphasized that the Persian characters were exceptional because they were plain: they made up "a very peculiar kind of alphabet, surpassing all others in simplicity, if I am not mistaken." 83

As Leibniz later remarked, this script was the invention of a sage, whereas all other alphabets were nothing but the barbarian deformations of the original Hebrew or Phoenician that had either been given by God to humankind

79 Cancik-Kirschbaum and Chambon, 'Les caractères en forme de coins' (see above, n. 32), $23-5$.

8o Letter of G. W. Leibniz to G. Cuper (26 October 1709), KB, MS $72 \mathrm{H} 17$ (see above, n. 24).

81 "Er hat sie nicht allein mit Indianischer Dinte, sondern auch meistentheils mit allerhand Wasserfarben nach dem Leben verfertigd, und zwar nicht als blose Entwürfe, sondern er hat sie jedesmal in loco, wie er versicherte, ausgearbeitet, und ausgeführt, mit dem Vorgrund und ganzer Ausstaffierung." Cited in Drijvers, 'Cornelis de Bruijn and Gijsbert Cuper' (see above, n. 33), p. 95.

82 Letter of G. Cuper to M. V. de La Croze ([the end of] 1715), in: Cuper, Lettres de critique (see above, n. 29), p. 178.

83 "Alphabeti genus plane singulare et aliis omnibus ni fallor praestans simplicitate," letter of G. W. Leibniz to G. Cuper (27 December 1707), KB, MS 72 H 17 (see above, n. 24). 
or devised by some Patriarch. ${ }^{84}$ Jean-Jacques Rousseau (1712-78) would later echo this observation when he stated "this character [i.e., cuneiform] is not at all deformed, nor barbarian." 85 Leibniz's remark is illuminating in more than one sense. He understood cuneiform script to constitute a phase in the history of writing that was completely independent of the Semitic-Greek-Latin family of alphabets. He also left open the question whether the Semitic-Greek-Latin family had entered the world by direct divine intervention or through the ingenuity of some unidentified pre-Mosaic individual.

Cuper made these views his own, either persuaded by Leibniz or arriving at them himself. A few months before he died, Cuper expressed what we may take to have been his final thought on the history of writing - the result of a quarter-century of exposure to an overwhelming variety of scripts. For once he abandoned his usual reticence toward his international peers, expounding in unequivocal terms what he had come to believe the most sensible position in his penultimate letter to La Croze. He appealed directly to the appearance of letters. He refused to believe that God had created the alphabet, not for Adam, Moses, or anyone else. Otherwise the various alphabets around the world would certainly have looked more alike. Tellingly, Cuper adduced the Persian cuneiform: even though these plain characters looked more like Hebrew letters than any other known script, on close inspection they turned out to have nothing in common with Hebrew. Given that there was so much diversity among scripts, even among those that at first glance might seem vaguely similar, Cuper concluded that there was no one single family to which all forms of writing could be reconnected. Writing must have been invented in several societies independently. Scripts were among the heurèmata, the crafty inventions of human beings. They were not to be attributed to the Pantokratōr, the Almighty God, but to human acuity. ${ }^{86}$

Thus, in Cuper we see how the formal appearance of letters became more meaningful to scholars during a period when meticulous graphic reproduction was at the forefront of technical innovation. More specifically, the formal diversity of alphabets played a decisive role in relocating the introduction of writing in the history of human societies. This was a period when world history was redefined, so that the seams that had held together the Bible, the Earth,

84 Letter of G. W. Leibniz to G. Cuper (30 July 1708), KB, MS $72 \mathrm{H} 17$ (see above, n. 24).

85 "Ce caractère [cunéiforme] n'a rien de confus ni de barbare," Jean-Jacques Rousseau, 'Essai sur l'origine des langues' (ca. 1754), in: idem, Traités sur la musique (Genève, 1781), pp. 209-325, there 233 .

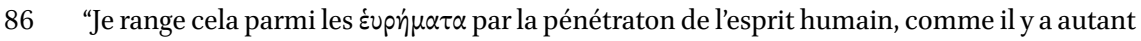
d'autres, qu'on s'étonne d'être inventez \& pratiquez, qu'on diroit devoir leur origine à Dieu

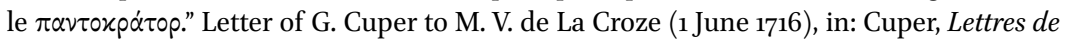
critique (see above, n. 29), p. 182. 
and human culture came loose as a consequence of biblical criticism, ethnographical observations, and antiquarian scholarship. The history of writing was but one of the forces which contributed to the unraveling of this fabric, but it shows particularly well how humanist philological expertise, combined with the craftsmanship of graphic artists in dealing with the stubborn material world, helped transform the biblical framework of world history.

The increased accuracy of reproductive techniques should have enabled scholars to establish the relationships among systems of alphabetic letterforms more easily. It might have been expected that as such techniques developed, the genealogy of scripts, and concurrently the genealogy of languages, and above all the genealogy of the peoples who had populated the various parts of the world, would have become more sharply drawn. Instead, the opposite happened. As experts in Europe received ever more accurate reproductions of exotic inscriptions, what really struck observers was their diversity. Cuneiform is a case in point. First interpreted as a highly stylized pictographic script, it ultimately appeared to Leibniz and Cuper to be analogous to the letters of an alphabet rather than to hieroglyphic or Chinese characters. Rather than being an addition to the known pictographic or ideographic scripts, it was an apparently alphabetic script. Nevertheless, despite the analogy, there was nothing in cuneiform that could formally be related to the Hebrew, Greek, or Latin alphabets. This led Cuper, for one, to conclude that the technique of writing was the result of human ingenuity, in various places, at various times.

The exchange of materials and ideas that led to this conclusion intersected at various points with the circulation of better-known strands in the history of ideas: the pre-Adamite thesis of Isaac La Peyrère, the relative antiquity of Judaic, Egyptian, and Chinese cultures discussed by Isaac Vossius and Georg Hornius, and the global esotericism of Athanasius Kircher. Cuper was intrigued by these topics, as shown by his indignation at the supposed statues of Adam and Eve and their progeny on Ceylon, and again by his curiosity when La Croze claimed to be able to relate Chinese to Coptic, Armenian to Median, and Sinhalese to Egyptian. Nevertheless, speculation about phonographic alphabets had a dynamic of its own, distinct from the discussions of ideography and pictography, and it was as much determined by technical sophistication as by critical argument. Moreover, the phonographic alphabet was more closely bound up with the providential history of God's chosen people. As such, for biblical religion the failure of Hebrew letters to retain their status as the 
primeval source of all other phonographic scripts was ultimately more consequential than the evident untenability of the idea that Chinese, Mexican, and Egyptian scripts could reveal one single, universally intelligible ideographic source.

Cuper is a striking example of how one academic, starting out solidly primed in the classics, experienced his awareness of the immensity of world history expand to the point that the framework of the Bible and classical antiquity could no longer encompass it. This newfound awareness affected his appreciation of writing and its place in world history. It is in the papers of Cuper that we see the notion of a linear progression, beginning with the Creation and extending through the Fall, the Flood, the Laws, Redemption, and ultimately the Last Judgment, yield in the face of proliferating fragments of knowledge about the world and its diverse inhabitants, who had developed widely divergent cultural traditions. Human achievements such as writing were progressively eased away from the compelling teleology of providential world history that was characteristic of confessionalized Christian culture. The multifarious cultural encounters thus had practical implications, which were as consequential as theoretical speculation for unraveling the coherence of a religiously informed world history. 